\title{
Markaðsáherslur og markaðshneigð
}

\author{
Pórhallur Örn Guðlaugsson. ${ }^{1}$
}

\begin{abstract}
Ágrip
Markaðshneigð (e. market orientation) má lýsa sem einkenni á fyrirtækjamenningu, sem birtist pannig að starfsmenn leggja sig fram við að veita viðskiptavininum, sem mestan ávinning af viðskiptum sínum við fyrirtækið. Markaðshneigð má einnig lýsa sem hegðun er styður markaðsáhersluna (e. marketing concept). Sú hegðun einkennist af víðtækri pekkingaröflun á breytingum í markaðsumhverfinu, miðlun peirrar pekkingar til eininga skipulagsheildarinnar og að viðbrögð hennar taki mið af pekkingunni.

Viðfangsefni pessarar greinar er markaðshneigð og markaðsáherslur og er augum sérstaklega beint að pví hvort opinber fyrirtæki geti, út frá forsendum markaðshneigðar, tileinkað sér markaðshneigð og markaðsleg vinnubrögð. Раð er mat höfundar, byggt á skoðun á stóru opinberu pjónustufyrirtæki, að pannig fyrirtæki geti tileinkað sér markaðshneigð í auknum mæli. Ýmsar hindranir séu pó í veginum sem m.a. má rekja til fyrirtækjamenningar og -skipulags. Einnig kemur fram í umræðunni að pólitískur hugsunarháttur getur verið skammt undan pegar um opinber fyrirtæki er að ræða. Hann getur haft neikvæð áhrif á viðleitni fyrirtækja til að auka markaðshneigð og markaðsleg vinnubrögð.
\end{abstract}

\begin{abstract}
Market orientation can be described as a business culture in which all employees are committed to creating maximum value for the customer. Market orientation can also be described as a behaviour that supports the marketing concept. That behaviour is characterized by organization-wide generation of market intelligence regarding current and future customer needs, dissemination of that intelligence across departments, and organization-wide responsiveness to it.

This paper focuses on market orientation and marketing philosophies as well as finding out whether public organizations can adopt market orientation and marketing methods. It is the author's opinion, based on a research of a large public organization, that such an organization can assume further market orientation. But there are still various hindrances, which may be traced to business culture among other things. Furthermore, it appears that partisanship often affects the discussion of public organizations. This may have negative effect on public organizations' efforts to increase market orientation and adopt marketing methods.
\end{abstract}

JEL flokkun: K2; L4

Lykilhugtök: markaðshneigð; markaðsáherslur

${ }^{1}$ Höfundur er lektor í Viðskipta- og hagfræðideild Háskóla Íslands. 


\section{Inngangur}

Viðfangsefni pessarar greinar er markaðshneigð (e. market orientation) og markaðsáherslur (e. marketing concepts). Markaðshneigð má lýsa sem fyrirtækjamenningu, sem birtist pannig að allir starfsmenn leggja sig fram við að veita viðskiptavininum sem mestan ávinning af viðskiptum sínum við skipulagsheildina. $^{2}$ Til að petta sé gerlegt parf að greina aðstæður í markaðsumhverfinu, miðla peim upplýsingum innan skipulagsheildarinnar og tryggja að hegðun hennar taki mið af peirri pekkingu sem verður til og grundvallast á upplýsingunum. Leiðirnar sem skipulagsheildirnar geta nýtt sér til að ná pessu fram eru m.a. markaðsrannsóknir, innra markaðsstarf og vel skilgreindir mælikvarðar á árangri.

Nokkurs misskilnings virðist gæta, hér á landi sem og erlendis, varðandi markaðsstarf og hlutverki pess innan fyrirtækja. ${ }^{3}$ Markaðsstarfið er gjarnan álitið snúast að mestu um auglýsingar og sölumennsku. Pá er litið svo á að hlutverk markaðsstarfsins sé fyrst og fremst að selja vörur og pjónustu fyrirtækja. Í peim tilgangi eru gylliboð látin dynja á neytendum í formi auglýsinga og persónulegrar sölumennsku.

Í upphafi greinarinnar er fjallað um próun markaðsfræðinnar, mismunandi rekstraráherslur og hvað faglegt markaðsstarf feli í sér. Gerð er grein fyrir áherslum og viðfangsefnum markaðsfræðinnar um aldamótin 1900 og hvernig fyrirtæki og stofnanir hafa tileinkað sér ólíkar rekstraráherslur í starfsemi sinni frá peim tíma til dagsins í dag. Hér er átt við framleiðsluáherslu (e. production concept), vöruáherslu (e. product concept), söluáherslu (e. selling concept), markaðsáherslu (e. marketing concept) og félagslega markaðsáherslu (e. societal marketing concept). Pessar mismunandi áherslur eru útskýrðar og hvað einkenni starf fyrirtækja og stofnana sem aðhyllast tiltekna áherslu.

Í priðja kafla greinarinnar er fjallað um markaðshneigð. Leitast er við að skilgreina hugtakið en fram kemur að margir höfundar gera ekki greinarmun á markaðshneigð og markaðsáherslu á meðan aðrir líta svo á að markaðshneigð sé afsprengi markaðsáherslunnar. Pessi umfjöllun byggir að stórum hluta á rannsóknarniðurstöðum Kohli og Jaworski (1990 og 1993) annars vegar og Narver og Slater (1990 og 1998) hins vegar. Rannsóknarniðurstöður peirra voru fyrst birtar árið 1990 og urðu pær til pess að auka áhuga fræðimanna á rannsóknum tengdum markaðshneigð. ${ }^{4}$

Í fjórða kafla er fjallað um markaðshneigð í tilteknu opinberu fyrirtæki. Höfundur kýs að tala um Fyrirtækið í stað pess að nefna pað á nafn og er pað fyrst og fremst gert til að gæta trúnaðar. Pessari umræðu er fyrst og fremst ætlað að styrkja fræðilega hlutann en ekki að koma á framfæri upplýsingum eða gagnrýni á Fyrirtækið. Раð er pví ekki talið pjóna tilgangi að pað sé nafngreint. Umræðan byggir á tveimur rannsóknum höfundar. Önnur var formleg eigindleg rannsókn (e. qualitative research) í formi djúpviðtala og pátttökuathugana en hin var óformleg athugun (e. observation) par sem m.a. var rætt við stjórnendur Fyrirtækisins, sem og

\footnotetext{
${ }^{2}$ Narver (1990).

${ }^{3}$ Sjá t.d. Kotler (2003), Adcock (1998), Day (1999) og Hollensen (2003).

${ }^{4}$ Narver (1998).
} 
stjórnendur nokkurra annarra opinberra fyrirtækja og stofnana, um markaðshneigð. Nánar er fjallað um pessar aðferðir í upphafi kaflans.

Í greininni eru dregnar vissar ályktanir um markaðshneigð opinberra fyrirtækja og stofnana. Prátt fyrir að ekki megi yfirfæra pessa umræðu yfir á öll opinber fyrirtæki og stofnanir, eiga pessar skipulagsheildir margt sameiginlegt, ekki síst hvað varðar menningu, ytri aðstæður, stjórnunarhætti, samskipti og skipulag. аð eru einkum peir hlutar markaðshneigðar sem tengjast pessum atriðum sem höfundur telur að megi yfirfæra að nokkru leyti almennt á opinbera og hálfopinbera starfsemi. Skiptir pá litlu hvort umrædd starfsemi hafi fyrst og fremst fjárhagsleg markmið að leiðarljósi, eða leggi megin áherslu á skilgreind pjónustumarkmið.

\section{Upphaf og próun markaðsfræða}

Skipulögð sölustarfsemi á sér langa sögu. Prátt fyrir pað var markaðsfræði ekki viðurkennd sem fræðigrein fyrr en í kringum 1910.5 Í upphafi beindist áhugi manna aðallega að landbúnaðarmörkuðum og var pá fyrst og fremst horft til tveggja viðfangsefna; sölu og verðmyndunar annars vegar og dreifileiða hins vegar. Námskeið, sem kennd voru í upphafi, byggðust að mestu leyti á hagfræði. ${ }^{6}$ Markaðsfræðin hefur próast mikið frá pessum tíma og má segja að nútíma markaðsfræði sé samsett grein, sem byggir m.a. á hagfræði, félagsfræði og sálarfræði. ${ }^{7}$

Framan af var fyrst og fremst litið á markaðssetningu sem afmarkað rekstrarhagfræðilegt viðfangsefni fremur en samhæfða stjórnun aðgerða eins og algengt er nú til dags. ${ }^{8}$ Árið 1948 settu samtök markaðsfræðinga í Bandaríkjunum (e. The American Marketing Association, AMA) fram skilgreiningu á markaðsfræði, sem breytti nokkuð skilningi manna á hugtakinu. ${ }^{9}$

\footnotetext{
"Markaðssetning fjallar um pær viðskiptalegu aðgerðir sem miðast við að stjórna flæði vara og pjónustu frá framleiðendum til neytenda."

The performance of business activities directed toward, and incident to, the flow of goods and services from producer to consumer.
}

Hér er pví litið á markaðssetningu sem röð aðgerða fremur en hugarfar, eins og algengt er nú, en markaðshneigð gerir ráð fyrir að fyrst og fremst sé um að ræða ákveðna hegðun og aðgerðir sem byggi á tilteknu hugarfari. ${ }^{10}$

Á sjötta og sjöunda áratugnum fékk markaðsfræðin mikla athygli og var pá almennt viðurkennd sem aðferð til að ná betri árangri í rekstri fyrirtækja. ${ }^{11}$ Á pessum tíma kom McCarthy fram með eitt pekktasta líkan markaðsfræðinnar, The four P's

\footnotetext{
${ }^{5}$ Webster (1992).

${ }^{6}$ Converse (1951).

${ }^{7}$ Kotler (2001).

8 Webster (1992).

${ }^{9}$ Webster (1992).

${ }^{10}$ Kohli (1990) sjá einnig Bisp (1999).

${ }^{11}$ Day (1983).
} 
$M$ odel $^{12}$, eða samval söluráđa, sem prátt fyrir nokkra gagnrýni og endurbætur, er enn í fullu gildi. Á mynd 1 má sjá nútímalega framsetningu á líkani McCarthy's en par er viðskiptavinurinn/markhópurinn settur í innsta hring, pá koma stjórnanlegu pættirnir, hér kallað samval söluráða, og yst óstjórnanlegu pættirnir í fjær (e. macro) umhverfinu.

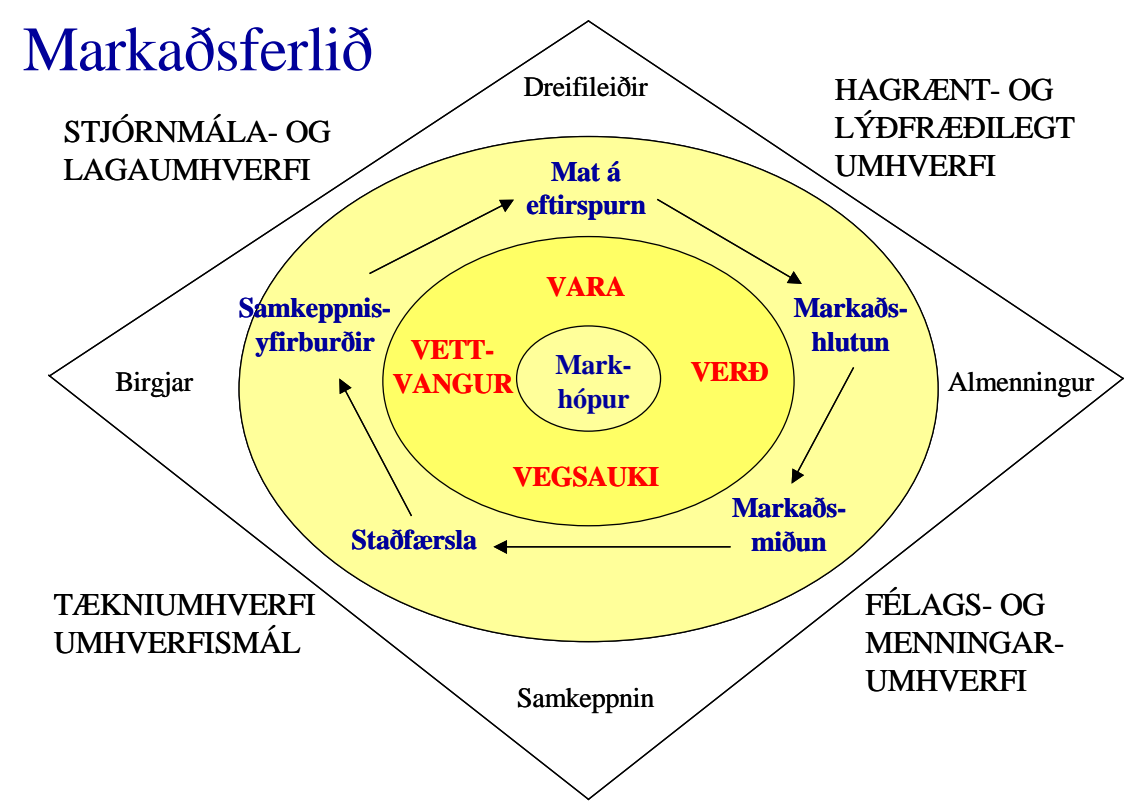

Mynd 1. Nútímaleg framsetning á líkani McCarthy's. ${ }^{13}$

Stjórnanlegu pættirnir eru P-in fjögur en pau standa fyrir vöru (e. product), verð (e. price), vettvang (e. place) og vegsauka (e. promotion). Á mynd 1 hefur svo verið bætt við pví sem kallað er miðuð markaðssetning ${ }^{14}$ (e. target marketing eða STPmarketing) en par sem ítarleg umfjöllun um раð efni er fyrir utan efni pessarar greinar verður ekki fjallað nánar um pað hér.

Sú gagnrýni sem fram hefur komið á skilgreiningu á markaðsfærslu tengist ekki síst peirri takmörkun sem líkan McCarthy's felur í sér. Pannig komu fljótlega fram hugmyndir um fleiri söluráða og kynnti Kotler (1986) hugtakið "megamarketing" par sem söluráðunum almannatengslum (e. public relation) og stjórnmálum (e. politics) er bætt við. Í markaðsfærslu pjónustu ${ }^{15}$ fjölgar pessum söluráđum enn frekar en hefðbundið er að tala um fólk (e. people), ferla (e. process) og umgjörð (e. physical evidence) og enn aðrir hafa viljað bæta áttunda söluráðanum við, framleiðni og gæðum (e. productivity and quality). ${ }^{16}$

Levitt (1960) lagði áherslu á að fyrirtæki og atvinnugreinar nýti sér hugmyndir markaðsfræðinnar og tileinki sér markaðsleg vinnubrögð. Par átti Levitt fyrst og fremst við tvennt. Annars vegar að fyrirtæki skilgreini starfsemi sína í víðara samhengi en áður og hins vegar að pau leitist við að hafa parfir viðskiptavina sinna

\footnotetext{
${ }^{12}$ Hunt (1978).

${ }^{13}$ Kotler (2001).

${ }^{14}$ Sjá Pórhallur Örn Guðlaugsson (2003).

${ }^{15}$ Sjá t.d. Zeithaml (2003).

${ }^{16}$ Sjá t.d. Lovelock (2002).
} 
að leiðarljósi við skipulagningu starfsemi sinnar. Á pað hefur verið bent að ef ætti að velja einhverja eina dagsetningu sem upphaf markaðshneigðar og markaðslegrar hugsunar í starfsemi fyrirtækja, pá sé pað einmitt birting greinar Levitt's. ${ }^{17}$

Á áttunda og níunda áratugnum beindust augu stjórnenda í auknum mæli að stefnumótun og stefnumiðaðri stjórnun og við pað dró úr áhrifum markaðsfræðinnar í rekstri fyrirtækja. ${ }^{18}$ Áhersla var lögð á fjárhagslega mælikvarða og samkeppnisstöðu. Pessi afstaða hefur verið kennd við samkeppnishneigð (e. competitor orientation) en pá miðast starfsemi fyrirtækisins fyrst og fremst við að skapa sér yfirburði í samkeppninni en síður á ánægju viðskiptavina. ${ }^{19}$ Margir höfðu efasemdir um grunnhugmyndafræði markaðsfræðinnar og enn aðrir drógu í efa að ánægja viðskiptavina skilaði sér í auknum hagnaði. ${ }^{20}$

Á tíunda áratugnum jókst svo aftur áherslan á markaðsleg vinnubrögð og má rekja pað til rannsókna Kohli og Jaworski (1990 og 1993) og Narver og Slater (1990 og 1998). ${ }^{21}$ Niðurstöður peirra sýndu fram á jákvæð tengsl milli markaðshneigðar og rekstrarárangurs og urðu pessar niðurstöður til pess að athygli fræðimanna á pessu rannsóknarefni jókst.

Nokkurs misskilnings virðist gæta hér á landi sem og erlendis varðandi eðli og hlutverk markaðsstarfs. Markaðsstarfið er gjarnan álitið snúast fyrst og fremst um að selja vörur og pjónustu fyrirtækja. Markaðsfræðin er í stöðugri próun og frá aldamótunum 1900 hafa fyrirtæki getað tileinkað sér ólíkar áherslur í markaðsstarfi sínu. Pessar áherslur eru framleiðsluáhersla, vöruáhersla, söluáhersla, markaðsáhersla og félagsleg markaðsáhersla. ${ }^{22}$

Framleiðsluáhersla (e. production concept) gerir ráð fyrir að neytendur vilji vörur sem eru ódýrar og auðfáanlegar. Fyrirtæki leggur pví allt kapp á að ná sem mestri hagkvæmni í framleiðslunni og sem víðtækastri dreifingu. Pessi afstaða fyrirtækja er skiljanleg við tvenns konar aðstæður. Annars vegar pegar markaðurinn er ekki í jafnvægi og eftirspurn eftir vörum fyrirtækisins er meiri en framboðið, pá skiptir öllu máli að leggja allt í að auka framleiðsluna. Hins vegar gæti pessi afstaða átt við pegar verð vörunnar er mjög hátt og reyna verður af öllum mætti að auka afköst og ná hærri framlegð pannig að hægt sé að bjóða hagstæðara verð og auka pannig markaðshlutdeild. Henry Ford náði árangri með pessa áherslu að leiðarljósi par sem lögð var áhersla á að lækka framleiðslukostnað sem mest, lækka verðið, og gera pannig fleirum kleift að eignast bifreið.

Vöruáhersla (e. product concept) gerir ráð fyrir að neytendur vilji hágæðavörur, sem slái aðrar vörur út hvað varðar einkenni og aukahluti. Fyrirtækið leggur pví mesta áherslu á að framleiða og endurbæta vörur sínar. Fyrirtæki, sem starfa með pessu hugarfari, lenda oft á villigötum. ${ }^{23}$ Talað er um að fyrirtækið sé tæknidrifið og á röngunni (e. technology-driven, inside-out firms). Fyrirtækið hefur á valdi sínu

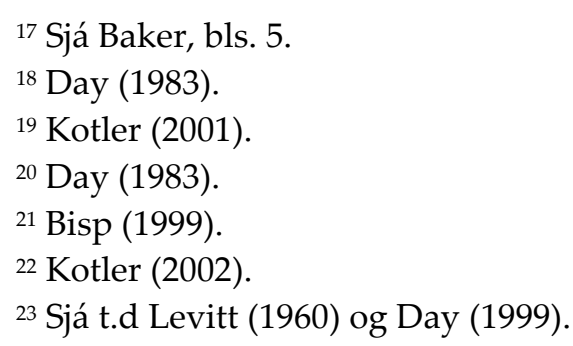


vissa tækni, dettur niður á vöru til að framleiða og líst óhemju vel á hana. Miklum tíma er eytt í að endurbæta vöruna og laga par til hún er orðin eins góð og mögulegt er. Stjórnendur fyrirtækis sem lenda í pessum aðstæðum átta sig ekki á pví að markaðurinn hefur hugsanlega ekki sama áhuga á vörunni og peir sjálfir. Varan selst pví ekki.

Kaupandinn gæti verið að leita að lausn á músagangi. Lausnin parf ekki endilega að vera betri músagildrur. Hún gæti verið fólgin í einhverju allt öðru sem gæti virkað mun betur en músagildrur gera. Hér er pví í raun ekki á ferðinni pörf fyrir músagildrur, heldur snýr pörfin að pví að losna við mýs.

Söluáhersla (e. selling concept) gerir ráð fyrir að séu neytendur látnir afskiptalausir, pá muni peir ekki kaupa nægilega mikið af vörum fyrirtækisins til að fullnægja kröfum um arðsemi. Starfsfólk verður pví að stunda "harða" sölu- og auglýsingastarfsemi. Pessi afstaða gerir ráð fyrir að ýta purfi við neytendum til að peir kaupi vörur fyrirtækisins. Völ er á fjölda auglýsinga og kynninga leiða og nauðsynlegt er að nota pær til að hvetja neytendur til að kaupa vörurnar. Söluafstöðunni hefur verið lýst á pann hátt, að markmið fyrirtækjanna sé að selja pað sem pau geta framleitt í stað pess að framleiða pað sem pau geti selt. ${ }^{24}$

IBM var lengi talið eitt af framsæknustu markaðsfyrirtækjum í heiminum. Petta átti ekki síst við meðal peirra sem stóðu utan við fyrirtækið en einnig meðal peirra er störfuðu innan pess. Í ljós kom að í stað pess að leggja áherslu á parfir og langanir viðskiptavina var áherslan á sölustarf. Viðfangsefnið var fyrst og fremst að fá neytendur til að kaupa pær vörur sem fyrirtækið bjó til. Skilningur var á kauphegðun neytenda og áhrifum kynningarstarfs á pá hegðun en minni á próun parfa í framtíðinni. Pessi mikla áhersla á sölu varð til pess að fyrirtækið missti af og vanmat tækifæri sem fólust í breyttu umhverfi. ${ }^{25}$

Markaðsáhersla (e. marketing concept) segir að til að ná markmiðum fyrirtækisins verði pað að skilgreina parfir og óskir markhópa sinna og fullnægja peim pörfum á skilvirkari og á hagkvæmari hátt en samkeppnisaðilarnir gera. Nú eru pað parfir og óskir viðskiptavinarins sem eru í fyrirrúmi og allt starf fyrirtækisins miðar að pví að fullnægja peim pörfum á hagkvæmari hátt en samkeppnisaðilarnir. Samkeppnisforskotið byggir á pekkingu á pörfunum, bæði núverandi og í framtíðinni, og peirri sýn að fyrirtækið eigi að velja sér pá markhópa par sem til staðar er pörf sem fyrirtækið getur pjónað með peim hætti sem að framan er talið. Day (1999) bendir á að stundum haldi fyrirtæki að pau séu markaðssinnuð eða markaðsdrifin, en séu pað alls ekki. Pannig geti fyrirtæki verið úr tengslum (e. oblivious to the market) við pað sem er að gerast á markaðnum, horfi fyrst og fremst inn á við og aðhyllist pví nokkurs konar sambland af framleiðslu- og vöruáherslu. Einnig geta pau verið pjökuð (e. compelled by the market) af kröfum og óskum markaðarins. Pessi fyrirtæki misskilja grundvallarpætti markaðsáherslunnar og telja að verða eigi við öllum óskum og kröfum viðskiptavina án nokkurrar stefnu eða aga í vinnubrögðum. Hér er athyglisvert atriði á ferðinni en svo virðist sem sumir telji að pað að hafa markaðsleg gildi að leiðarljósi feli í sér blinda viðleitni í að verða við kröfum markaðarins. Til pessa má rekja pað sjónarmið að viðskiptavinurinn hafi ætíð rétt fyrir sér (e. the customer is always right) en rannsóknir benda til pess að svo

\footnotetext{
${ }^{24}$ Kotler (2001).

${ }^{25}$ Day (1999).
} 
sé ekki í mörgum tilvikum. ${ }^{26}$ Рað að viðskiptavinurinn hafi ekki efnislega rétt fyrir sér, pýðir ekki að hann eigi ekki sinn rétt. Viðskiptavinurinn hefur rétt á að koma óskum sínum á framfæri, kvarta yfir pví sem hann telur að hafi farið miður, og fá pá pjónustu sem lofað var. Að síðustu bendir Day (1999) á að fyrirtæki geti verið hafin yfir markaðinn (e. superior to the market). Fyrirtækin séu gjarnan tækni- og söludrifin og aðhyllist pví sambland af vöru- og söluáherslu. Stundi pví takmarkaðar markaðsrannsóknir og líti svo á að pau, p.e. fyrirtækin, viti best hvað sé viðskiptavininum fyrir bestu.

Söluáherslunni er gjarnan ruglað saman við markaðsáhersluna, p.e. pað sem talið er markaðsdrifið fyrirtæki er í raun söludrifið. Ákveðinn munur er á sölu- og markaðsáherslu og er honum gjarnan lýst pannig að söluafstaðan leggi áherslu á parfir seljandans á meðan markaðsafstaðan leggi áherslu á parfir kaupandans. ${ }^{27}$ Stjórnendur fyrirtækis sem aðhyllast söluáherslu eru uppteknir af pví að umbreyta vörum sínum í peninga og mynda á pann hátt hagnað, en stjórnendur sem aðhyllast markaðsáherslu eru uppteknir við að fullnægja pörfum viðskiptavinarins, með sampættu markaðsstarfi alls fyrirtækisins, við próun, gerð, afhendingu og pjónustu vörunnar og reyna pannig að mynda hagnað í fyrirtækinu. Á mynd 2 má sjá samanburð á söluáherslu og markaðsáherslu. Til einföldunar er talað um að í söluáherslu hefjist ferlið í fyrirtækinu en í markaðsáherslu pá hefjist pað á markaðnum. Í söluáherslu er lögð áhersla á núverandi vörur og til að selja pær er stuðst við sölustarfsemi og auglýsingar. Í markaðsáherslu er fyrst og fremst lögð áhersla á að greina parfir viðskiptavina og stuðst er við pað sem er kallað sampætt markaðsfærsla (e. integrated marketing). Pá er pess gætt að ákveðið samræmi sé milli markaðsaðgerða fyrirtækisins, s.s. vörupróunar, verðákvarðana, dreifileiðaákvarðana og samvals kynningarráða (e. promotion mix). ${ }^{28}$

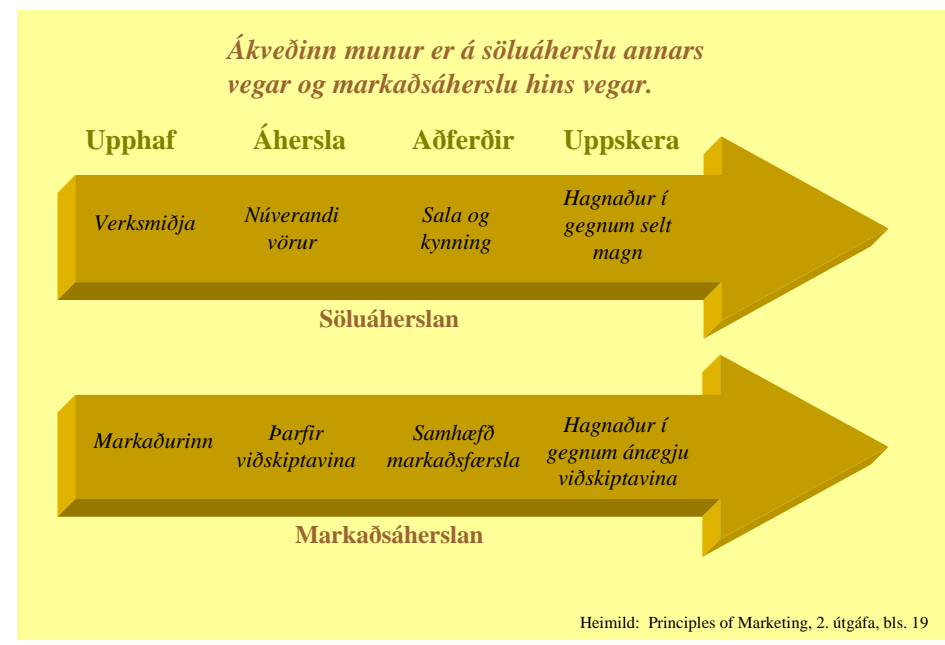

Mynd 2. Samanburður á sölu- og markaðsáherslu.

Í augum leikmanna er gjarnan litið á sölustarf og auglýsingar annars vegar og markaðsstarf hins vegar sem eitt og hið sama. аð parf í raun ekki að koma á óvart

\footnotetext{
${ }^{26}$ Sjá t.d. Zeithaml (2003) bls. 169-174.

${ }^{27}$ Kotler (2001).

${ }^{28}$ Kynningarráðarnir eru fimm, p.e. auglýsingar, persónuleg sala, almannatengsl, söluaukar og bein markaðsfærsla.
} 
ef tekið er mið af öllum peim fjölda auglýsinga sem dynja á neytendum dag hvern ásamt beinskeyttum söluherferðum. ${ }^{29}$ Auglýsingar og persónuleg sölumennska eru fyrst og fremst verkfæri til að auka sölu og parf ekki að pýða að fyrirtæki hafi markaðsleg gildi að leiðarljósi í starfsemi sinni. аð væri í raun eins og að segja að sá er kaupir hamar sé par með orðinn smiður. Á pessu hafa mörg fyrirtæki áttað sig og nokkuð hefur dregið úr vægi auglýsinga í kynningarstarfi. ${ }^{30}$ Einnig hefur nú síðustu ár komið fram sterk gagnrýni á ofnotkun auglýsinga og á pað bent að aðrar leiðir, t.d. almannatengsl (e. public relation), gætu verið mun vænlegri til ná settu markmiði. ${ }^{31}$ Ennfremur er í flestum fræðibókum um markaðsfræði varað við ofnotkun auglýsinga og lögð áhersla á sampætt markaðsstarf. ${ }^{32}$

Í báðum áherslunum er markmiðið hagnaður.33 Í söluáherslunni skapast hagnaður af seldu magni og markaðshlutdeild en í markaðsáherslunni byggist hagnaðurinn á ánægju viðskiptavina. ${ }^{34}$ Með pví er ekki átt við að gera eigi allt, sem viðskiptavinurinn óskar eftir og að hann hafi óhjákvæmilega rétt fyrir sér. Oft veit viðskiptavinurinn ekki hvað honum sjálfum er fyrir bestu. Petta á t.d. við pegar pjónusta er í eðli sínu flókin, s.s. lögfræðipjónusta, heilbrigðispjónusta og kennsla. ${ }^{35}$ Pað sem er átt við með pessu er að fyrirtækið vill pekkja parfirnar, standa við pá lausn sem var lofuð og stuðla pannig að pví að viðskiptavinurinn komi aftur. Markaðsfærsla byggð á samböndum (e. relationship marketing) og stjórnun viðskiptatengsla (e. customer relationship management, CRM), er pví eitt af lykilatriðum í nútíma rekstri. ${ }^{36}$

Hér parf pó að hafa í huga að ekki hafa allar skipulagsheildir hagnað að aðalmarkmiði, p.e. árangur verður ekki metinn út frá hagnaðarstigi og jafnvel ekki hefðbundnum fjárhagslegum mælikvörðun. Mikilvægt er fyrir pannig skipulagsheildir að finna og greina mælikvarða til að meta árangur. Petta kemur hins vegar ekki í veg fyrir að starfsemin geti tileinkað sér markaðsleg vinnubrögð par sem lögð er áhersla á að fullnægja pörfum og óskum einstaklinga eða hópa á markaði. ${ }^{37}$

Félagsleg markaðsáhersla (e. societal marketing concept) hefur fengið aukið vægi síðustu ár og gerir ráo fyrir pví að markmið fyrirtækisins sé að skilgreina parfir, óskir og áhugamál markhópa sinna og fullnægja peim betur en samkeppnisaðilarnir gera. Раð verði pó að gerast á pann hátt að hagur neytenda og pjóðfélagsins í heild sé ætíð hafður að leiðarljósi.

\footnotetext{
${ }^{29}$ Kotler (2001).

${ }^{30}$ Hagstofa Íslands (1999). Fjölmiðlun og menning.

${ }^{31}$ Sjá t.d. Ries (2002).

${ }^{32}$ Sjá t.d. Kotler (2003), Belch (2001), Bagozzi (1998) og Hollensen (2001).

${ }_{33}$ Petta á fyrst og fremst við um fyrirtæki sem hafa hagnað að megin markmiði. Aðrar skipulagsheildir, s.s. opinber fyrirtæki og stofnanir, sem ekki hafa hagnað að megin markmiði (not-for-profit Organization) stefna pá að pví að veita sem besta pjónustu með sem hagkvæmustum hætti.

${ }^{34}$ Hollensen (2003).

${ }^{35}$ Zeithaml (2003).

${ }^{36}$ Zinkham (2001).

${ }^{37}$ Anreasen (2003).
} 
Pessa áherslu má rekja til skrifa Kotlers og Levy's ${ }^{38}$ um nauðsyn pess að útvíkka markaðshugtakið og láta pað ná yfir aðra starfsemi en pá sem hefur hagnað að megin markmiði. Einnig hefur gagnrýni á markaðsstarf farið vaxandi síðustu ár sem hefur gert pað að verkum að fyrirtæki hafa skilgreint markmið sín önnur en aðeins pau að skapa hluthöfum sínum sem mestan arð. ${ }^{39}$

Á mynd 3 má sjá að lögð er áhersla á jafnvægi milli parfa samfélagsins, viðskiptavinarins og skipulagsheildarinnar.

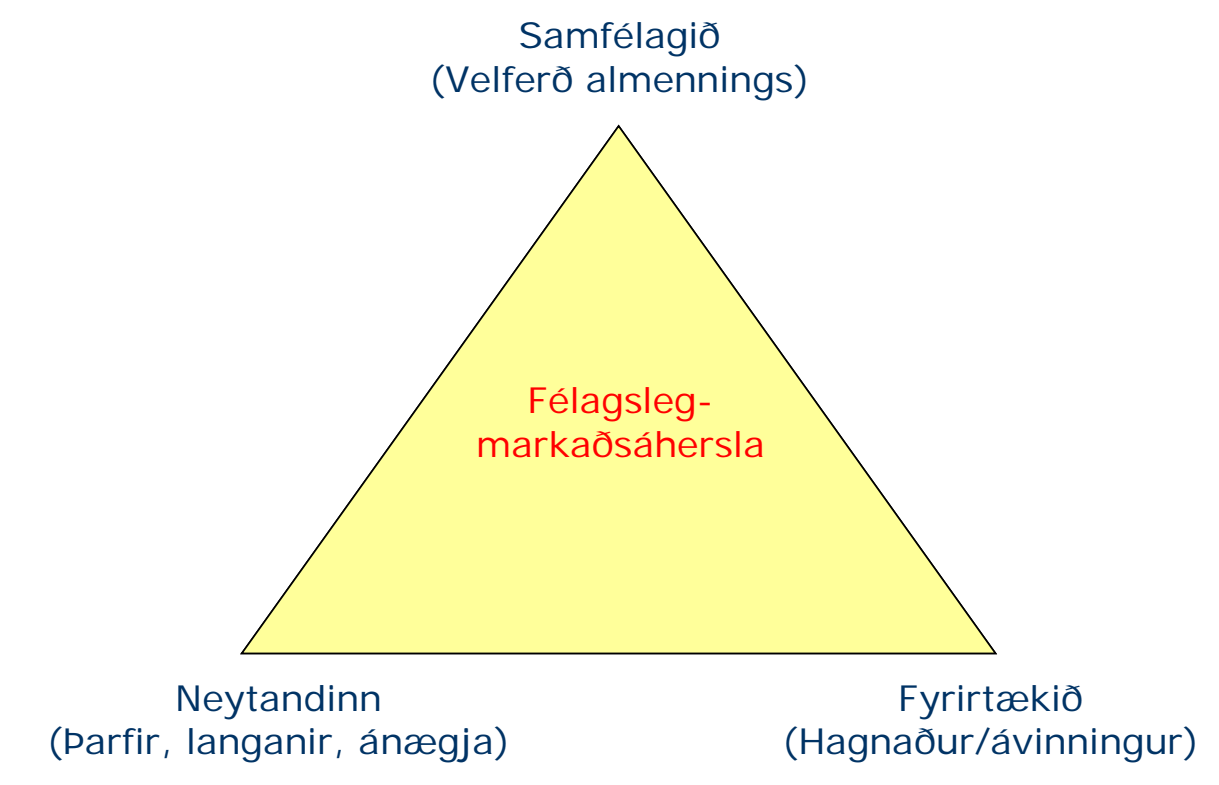

Mynd 3. Grunnstoðir félagslegrar markaðsáherslu.

Félagsleg markaðsáhersla tekur tillit til pess að margar pjóðir búa við umhverfisvandamál, skort á auðlindum og samfélagslegri pjónustu. ${ }^{40}$ Sjónarmið félagslegrar markaðsáherslu er að hefðbundin markaðsáhersla horfi framhjá hugsanlegu ósamræmi milli skammtíma langana fólks annars vegar, og langtíma velferðar peirra hins vegar.

\section{Skilgreining á markaðshneigð}

Prátt fyrir að hugsunin á bak við markaðshneigð hafi verið hornsteinn markaðsfræðinnar allt frá miðri síðustu öld, hafði lítið sem ekkert verið reynt að skilgreina hugtakið eða rannsaka áhrif peirra vinnubragða á árangur fyrirtækja fyrir 1990.41 Lítið hafði verið rannsakað hvernig ætti að innleiða markaðshugsunina inn í fyrirtækin. Markaðsfræðin hafði verið flokkuð sem nokkurs konar viðskiptaleg

\footnotetext{
38 Sjá Hunt (1976).

${ }^{39}$ Um petta sjónarmið eru síður en svo allir sammála. Pannig hefur Milton Friedman látið eftirfarandi skoðun í ljós: "Few trends could so thoroughly undermine the very foundations of our free society as the acceptance by corporate officials of a social responsibility other than to make as much money for their stockholders as possible."

40 Kotler (2001).

${ }^{41}$ Narver (1990).
} 
heimspeki, sem endurspeglast í stefnu eða stefnuyfirlýsingu skipulagsheilda. Ekki er pó alltaf samræmi milli raunverulegrar starfsemi og yfirlýstrar markaðsstefnu. ${ }^{42}$

Almennt er talið meðal fræðimanna innan markaðsfræðinnar að viðleitni til að kanna viðhorf viðskiptavina til pjónustu og nýta sér pá pekkingu til að bæta pjónustuna annars vegar og hins vegar til að leggja mat á árangur fyrirtækisins, grundvallist á pví að skipulagsheildir tileinki sér markaðshneigð og markaðsleg vinnubrögð. ${ }^{43}$

Í pessum kafla er leitast við að skilgreina hugtakið markaðshneigð og hvað einkenni starfsemi sem hefur markaðsleg gildi að leiðarljósi. Eftir pví sem valkostum neytenda til að fullnægja pörfum sínum og löngunum hefur fjölgað pví mikilvægara er fyrir fyrirtæki að auka gæði vara sinna hvort sem um er að ræða ápreifanlegar vörur eða pjónustu. Par sem parfir og væntingar neytenda taka breytingum frá einum tíma til annars er mikilvægt að fylgjast grannt með peim breytingum og mæta peim með viðeigandi hætti. ${ }^{44}$ Segja má að hér sé um víðtæka skilgreiningu á markaðshneigð аð ræða en pess ber аð geta аð markaðshneigð er skilgreind með ýmsum hætti og ekki alltaf gerður greinarmunur á markaðshneigð (e. marketorientation) og markaðsáherslu (e. marketing-concept) enda virðast höfundar bóka um markaðsfræði og markaðsmál nota pessi hugtök jöfnum höndum. Ýmsir fræðimenn telja óljóst við hvað er átt pegar talað er um markaðshneigð eða markaðsáherslur, skilgreiningar séu óljósar og pokukenndar, sem hefur pau áhrif að skipulagsheildir sem vilja tileinka sér slíka hugsun eða vinnubrögð viti ekki hvað felst í pví. ${ }^{45}$ Höfundur telur að nauðsynlegt sé að gera á pessu skýran greinarmun og vill líta á markaðsáhersluna sem tiltekna hugmyndafræði eða viðskiptaspeki á meðan markaðshneigð er hegðun sem byggir á og styður pá hugmyndafræði. Verður petta nánar útskýrt í framhaldinu.

Algenga skilgreiningu á markaðsáherslunni má finna hjá Kotler (2001) en par er hún skilgreind sem...

"Hugmyndafræði við stjórnun fyrirtækja par sem gengið er út frá
pví að til að ná markmiðum fyrirtækisins purfi að skilgreina parfir
og langanir markhópa pess og fullnægja peim pörfum á skilvirkari
og hagkvæmari hátt en samkeppnisaðilarnir gera."
The marketing management philosophy which holds that achieving
organisational goals depends on determining the needs and wants of target
markets and delivering the desired satisfactions more effectively and
efficiently than competitors do.

Adcock (1998) leggur augljóslega sama skilning í hugtökin markaðshneigð og markaðsáherslu. Sama má segja um nálgun Bagozzi o.fl. (1998), Hill og O'Sullivan (1996), Peter (2001), Hollensen (2003) og Winer (2001), en hjá öllum pessum höfundum má finna sambærilegar skilgreiningar, sem bendir til pess að meðal margra fræðimanna virðist ekki gerður skýr greinarmunur á markaðshneigð og

\footnotetext{
${ }^{42}$ Kohli (1990).

${ }^{43}$ Best (1997).

${ }^{44}$ Kotler (2001).

${ }^{45}$ Sjá t.d. Hunt (1978), Dreher (1994) og Day (1999).
} 
markaðsáherslu. Раð sem skilgreiningarnar ${ }^{46}$ eiga sameiginlegt er að viðskiptavininum, pörfum hans og löngunum, er gert afar hátt undir höfði og í raun litið svo á að aðeins með pví móti megi ná árangri við aðstæður par sem parfir og langanir eru síbreytilegar og til staðar er samkeppni um að fullnægja pessum pörfum betur en aðrir á markaðinum. Eðlilegt val viðskiptavina, sem birtist í samkeppni peirra fyrirtækja er starfa á markaðinum, er pví ein af grunnstoðum markaðsáherslunnar.

Í skilgreiningu sinni á markaðshneigð ${ }^{47}$, leggur Kotler (2001) áherslu á jafnvægi milli viðskiptavinahneigðar (e. customer orientation) og samkeppnishneigðar (e. competitor orientation). Á mynd 4 má sjá að pegar skipulagsheild aðhyllist vöruhneigð pá er lítil áhersla á parfir viðskiptavina og pá samkeppni sem ríkir á markaðinum. Pessar aðstæður koma gjarnan upp par sem samkeppni er af skornum skammti.

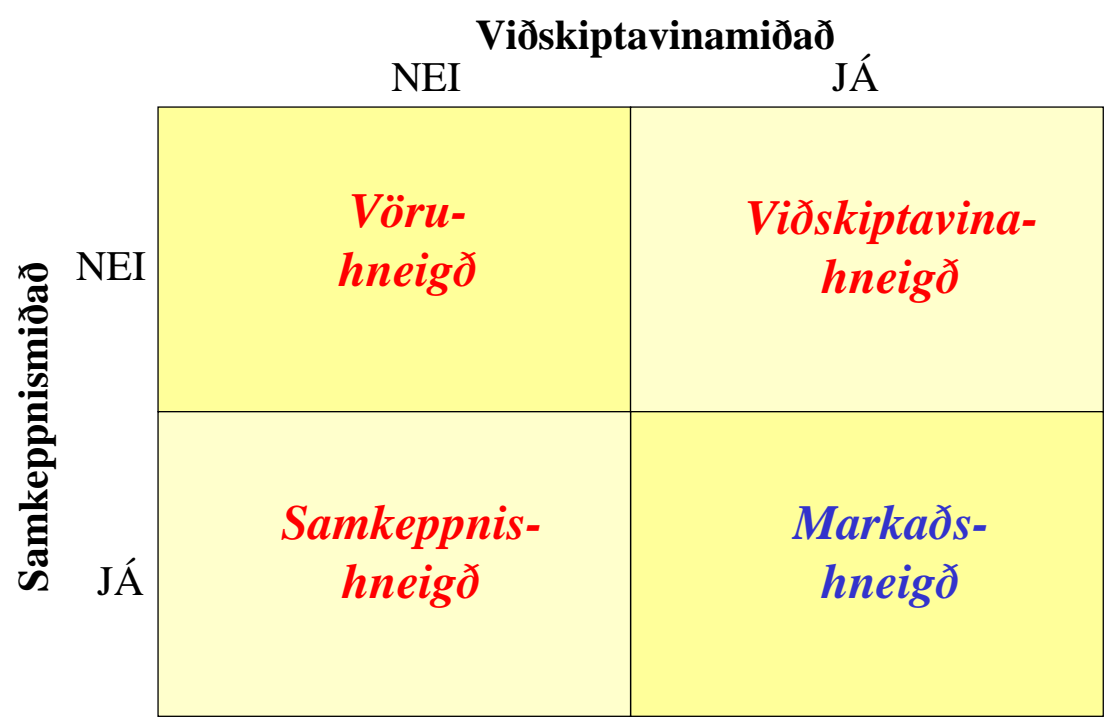

Mynd 4. Jafnvægi viðskiptavinahneigðar og samkeppnishneigðar.

Fyrirtæki sem aðhyllist samkeppnishneigð leggur höfuðáherslu á að bregðast við aðgerðum samkeppnisaðila. Hér vaknar sú spurning hvort fyrirtæki geti lagt of mikla áherslu á samkeppni og skaðað pannig mikilvæga vinnu, sem tengist greiningu á pörfum viðskiptavina sinna. Vissulega getur fyrirtæki orðið of upptekið af samkeppninni og misst pannig sjónar á breyttum pörfum og löngunum. Allt kapp er lagt á að svara tilboði samkeppnisaðilans og að finna leiðir til að gera betur. Pessi stefna, eins og allar stefnur, hefur kosti og galla. Kostirnir eru peir að skipulagsheildin er mjög vakandi fyrir breytingum. Starfsmenn eru hvattir til að fylgjast vel með veikleikum skipulagsheildarinnar, sem og veikleikum samkeppnisaðilanna. ${ }^{48}$ Gallarnir eru hins vegar peir að hætt er við að

\footnotetext{
${ }^{46}$ Höfundar nota mörg hugtök yfir pað sem hér um ræðir, ss.s. market-driven, marketfocused, market-oriented, market-centred, marketing-concept.

47 Í umfjöllun sinni tala Kotler og félagar samtímis um market-centred og market-oriented companies.

${ }^{48}$ Kotler (2001).
} 
skipulagsheildin verði um of "teymd" (e. reactive) í starfsemi sinni, í stað pess að vera "leiðandi" (e. proactive). Í stað pess að halda staðfastlega við sína eigin stefnu, er um of tekið mið af stefnu og aðgerðum samkeppnisaðilans og í raun gengið út frá pví að samkeppnisaðilinn viti betur hvernig starfa eigi á tilteknum markaði. ${ }^{49}$

Viðskiptavinahneigð leggur hins vegar höfuðáherslu á viðskiptavininn og parfir hans. Samanborið við samkeppnishneigð er pessi stefna mun líklegri til að greina tækifæri á markaði og jafnvægi skapast á milli parfa og óska á markaði og getu fyrirtækisins til að fullnægja peim. ${ }^{50}$ Gallinn við pessa aðferð er fyrst og fremst sá að of mikil áhersla er lögð á parfir og óskir viðskiptavinarins og horft fram hjá samkeppninni sem leitast við að pjóna pessum pörfum á hagkvæmari og skilvirkari hátt.

Í skilgreiningu sinni á markaðshneigð leggur Kotler (2001) áherslu á jafnvægi milli samkeppnishneigðar og viðskiptavinahneigðar eins og áður hefur komið fram. Mikilvægt sé að hafa parfir og óskir viðskiptavina að leiðarljósi en jafnframt purfi að taka mið af aðgerðum og stefnu samkeppnisaðila og móta eigin aðgerðir og stefnu út frá pví. Að pekkja styrk og veikleika samkeppnisaðilans er pví jafn mikilvægt og að pekkja eigin styrk og veikleika. ${ }^{51}$

Kohli (1990) og Jaworsky tala um markaðshneigð sem innleiðingu á markaðsáherslunni. Pannig einkennist hegðun markaðshneigðs fyrirtækis af athöfnum sem taki sterkt mið af markaðsáherslunni. Pannig gera peir á pessu skýran greinarmun, p.e. markaðsáherslan sé undirliggjandi hugmyndafræði á meðan markaðshneigðin er hegðun sem taki mið af peirri hugmyndafræði. Markaðshneigð sé pví ekki annað hvort eða verkefni, heldur sé markaðshneigð á tilteknu stigi, p.e. sumar athafnir taki sterkt mið af markaðsáherslunni á meðan aðrar gera pað síður. Pannig er markaðshneigð skilgreind sem...

“...víðtæk pekkingaröflun á breytingum i markaðsumhverfinu,
miðlun pessarar pekkingar til eininga skipulagsheildarinnar og að
viðbrögð hennar taki mið af pessari nýju pekkingu."
Organization wide generation of market intelligence to current and future
customer needs, dissemination of the intelligence across departments, and
organization wide responsiveness to it.

Gengið er út frá pví að afla purfi pekkingar á pörfum og löngunum viðskiptavina, miðla purfi peirri pekkingu innan skipulagsheildarinnar og tryggja að hegðun hennar í framtíðinni taki mið af pessari nýju pekkingu. Innleiðing á markaðshneigð sé pví eins og hefðbundið lærdómsferli, par sem nýrri pekkingu er miðlað og sú pekking leiði af sér breytta hegðun. ${ }^{52}$

Á mynd 5 má sjá að Kohli og Jaworski líta á markaðshneigð sem ákveðið ferli, sem í raun aldrei tekur endi. Раð parf stöðugt að fylgjast með breytingum á umhverfinu og skilgreina skipulag og aðstæður, sem leiði til pess að pekkingu er

\footnotetext{
${ }^{49}$ Belch (2001).

${ }^{50}$ Kotler (2001).

${ }^{51}$ Hollensen (2003).

52 Probst (1997).
} 
miðlað. Ný pekking hefur áhrif á hvaða leiðir eru farnar í peirri viðleitni að ná betri árangri.

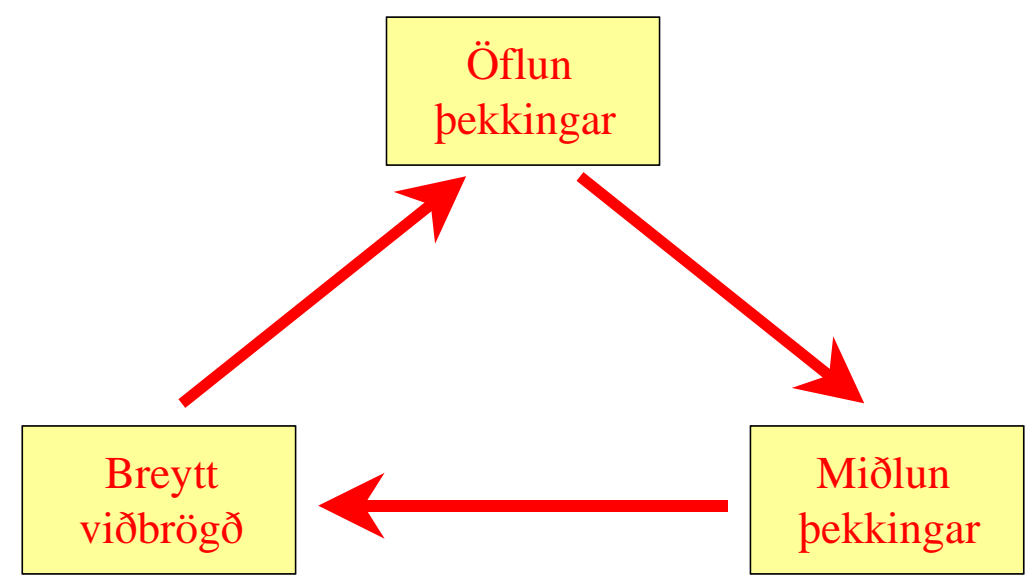

Mynd 5. Grunnstoðir markaðshneigða sbr. Kohli og Jaworski.

Í rannsóknum sínum ${ }^{53}$ sýndu Kohli og Jaworski fram á sterkt samband markaðshneigðar og árangurs skipulagsheildarinnar. Árangur var skilgreindur á premur sviðum. Í fyrsta lagi pað sem snýr að viðskiptavininum en par er æskilegur árangur skilgreindur sem ánægja viðskiptavina og endurtekin viðskipti. Í öðru lagi er litið á árangur út frá fjárhags- og rekstrarlegum mælikvörðum par sem niðurstaðan er aukinn hagnaður og í priðja lagi er horft á árangur í ljósi starfsmannamála par sem niðurstaðan er samstaða, ánægja starfsmanna og tryggð við fyrirtækið.

Narver (1998) og félagar tala um markaðshneigð sem tilteknar athafnir og hegðun sem endurspeglist í fyrirtækjamenningu og skilgreina markaðshneigð sem...

“... fyrirtækjamenningu par sem allir starfsmenn eru trúir poí að
veita viðskiptavininum sem mestan ávinning af
viðskiptum/samskiptum sínum við skipulagsheildina."
Market Orientation is a business culture in which all employees are
committed to the continuous creation of superior value for customer.

Narver og Slater (1990) birtu sínar rannsóknir um svipað leyti og Kohli og Jaworski. Peir sýndu fram á marktæk tengsl milli markaðshneigðar annars vegar og arðsemi, sölu og velgengni nýrra vara hins vegar. Í sinni nálgun lögðu peir áherslu á prjá hegðunarpætti; viðskiptavinahneigð, samkeppnishneigð og sampætt markaðsstarf (e. interfunctional coordination). Hér er viðskiptavinahneigð skilgreind sem stöðug viðleitni til að skilja parfir og langanir núverandi og væntanlegra viðskiptavina og að nýta pá pekkingu til að auka ávinning peirra. Samkeppnishneigð er skilgreind sem stöðug viðleitni til að skilja getu annarra til að fullnægja sömu pörfum og fyrirtækið eða stofnunin gerir. Athygli vekur að bæði í umfjöllun um viðskiptavinahneigð og samkeppnishneigð er talað um að stöðug vinna purfi að eiga sér stað og markmiðið

\footnotetext{
${ }^{53}$ Sjá Kohli (1990) og Jaworski (1993).
} 
sé að öðlast skilning og pekkingu á tilteknum aðstæðum. Á mynd 6 má sjá markaðshneigð eins og Narver og Slater skilgreina hana.

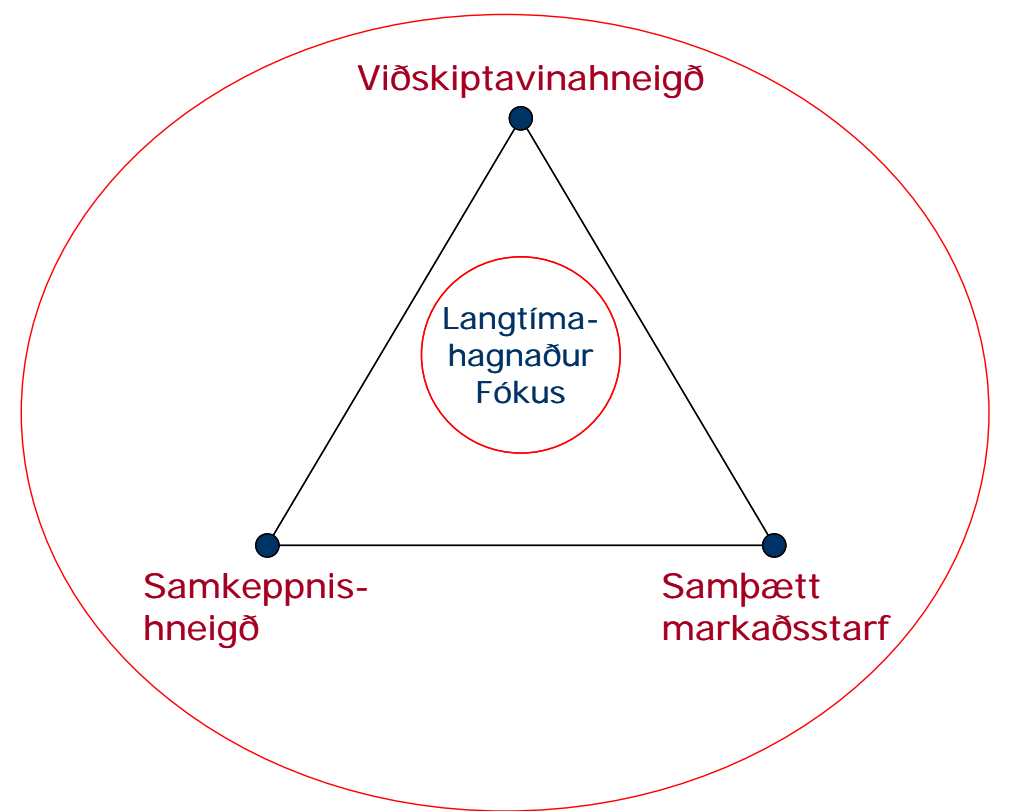

Mynd 6. Grunnstoðir markaðshneigðar sbr. Narver og Slater.

Með sampættu markaðsstarfi er einfaldlega átt við að öll starfsemin purfi að miða að pví að ná markmiðunum og pað verði ekki gert öðruvísi en með pví að skilja og pekkja parfir viðskiptavinanna, sem og styrk og veikleika samkeppnisaðilanna. Pannig séu allir, alltaf, að stunda markaðsstarf en ekki aðeins peir sem venjulega eru kallaðir markaðsmenn eða markaðsfólk.

Megindlegar rannsóknir á markaðsstarfi (e. quantitative research) hafa sýnt fram á jákvæð tengsl markaðshneigðar og árangurs. Ennfremur hafa niðurstöður sýnt fram á að tengslin eru óháð mörkuðum eða tegund starfsemi. ${ }^{54}$ Nokkur munur er hins vegar á pví hvort fræðimönnum hafi tekist að sýna fram á bein eða óbein tengsl við árangur. Pannig sýndu Baker og Sinkula (2002) fram á fylgni milli markaðshneigðar og nýsköpunar sem hefði svo bein áhrif á árangur. Áður höfðu Baker og Sinkula (1999) vakið athygli á pví að markaðshneigð ein og sér dygði ekki til árangurs, heldur pyrfti sterka lærdómshneigð (e. learning orientation) samfara markaðshneigðinni. ${ }^{55}$

Prátt fyrir petta virðist ganga hægt að auka markaðshneigð og pau vinnubrögð sem henni fylgja. Fyrir pví eru ýmsar ástæður, s.s. stjórnunarlegar, samskiptalegar og skipulagslegar hindranir ${ }^{56}$, en einnig virðist misskilningur á eðli markaðshneigðar lífseigur. ${ }^{57}$ Skipulagsheildunum virðist ganga illa að starfa samkvæmt pví viðmiði að skapa viðskiptavininum aukinn ávinning og eiga erfitt með að skynja breytingar sem "norm" en ekki undantekningu. Jafnframt er nauðsynleg forysta oft ekki til staðar, svo að hægt sé að innleiða markaðshneigð með árangursríkum hætti. Margir virðast

\footnotetext{
${ }^{54}$ Narver (1998).

55 Sjá einnig Farrell (2002).

56 Bisp (1999).

57 Day (1999).
} 
pví ennpá álíta markaðsstarf og markaðsstjórnun fyrst og fremst snúast um sölustarf og auglýsingamennsku. ${ }^{58}$ Nútíma markaðsstarf og markaðsstjórnun tekur tillit til mun fleiri pátta. Раð gengur fyrst og fremst út á að innleiða og viðhalda peim einkennum á fyrirtækjamenningu sem gerir ráð fyrir að allir starfsmenn einbeiti sér að pví að veita viðskiptavininum sem mestan ávinning af viðskiptum eða samskiptum sínum við skipulagsheildina. ${ }^{59}$ Til að petta sé gerlegt parf að greina aðstæður í markaðsumhverfinu, miðla peim upplýsingum innan skipulagsheildarinnar og tryggja að hegðun hennar taki mið af hinni nýfengnu pekkingu. ${ }^{60}$ Leiðirnar sem skipulagsheildirnar hafa til að ná pessu fram eru meðal annars markaðsrannsóknir, innra markaðsstarf og vel skilgreindir mælikvarðar á árangur. ${ }^{61}$

\section{Markaðshneigð í opinberum rekstri}

Jaworski (1993) og Kohli (1990) ásamt Narver og Slater (1990) eru peir aðilar sem fyrstir sýndu fram á tengsl markaðshneigðar við árangur skipulagsheildar. ${ }^{62}$ Í rannsókn Kohli (1990) og Jaworski eru kynntar tilgátur varðandi forsendur, áhrifapætti og áhrif markaðshneigðar. Peir fylgja pessari forrannsókn eftir og eru niðurstöður hennar birtar 1993.63 Niðurstöður peirrar rannsóknar sýndu fram á að markaðshneigð hefði afgerandi áhrif á frammistöðu skipulagsheildarinnar, óháð óróa á markaði (e. market turbulence), samkeppnisstigi (e. competitive intensity) eða tæknipróun (e. technological turbulence). ${ }^{64}$ Ótal rannsóknir sem siglt hafa í sama kjölfar styðja pessar niðurstöður í meginatriðum. ${ }^{65}$ Af pessu má sjá að pað er mikilvægt fyrir stjórnendur að leggja áherslu á að styrkja markaðshneigð í skipulagsheildinni með pað í huga að bæta frammistöðuna, hvort sem skipulagseiningin hefur hagnað að meginmarkmiði eða ekki.

Í umfjölluninni hér á eftir verður skoðað með hvaða hætti opinbert fyrirtæki, hér eftir nefnt Fyrirtækið, getur aukið markaðshneigð í starfsemi sinni og hvað komi helst í veg fyrir pað. Umræðan byggir á tveimur rannsóknum höfundar, önnur ${ }^{66}$ er formleg eigindleg rannsókn í formi djúpviðtala og pátttökuathugana en hin er óformleg athugun. ${ }^{67}$

Fyrri rannsóknin var rannsókn par sem beitt var viðtölum og pátttökuathugunum en hvorutveggja eru hefðbundnar aðferðir í eigindlegum rannsóknum. Rannsóknarsniðið voru starfsmenn og millistjórnendur Fyrirtækisins

\footnotetext{
${ }^{58}$ Kotler (2001).

${ }^{59}$ Narver (1998).

${ }^{60}$ Kohli (1990).

${ }^{61}$ Kotler (2001).

${ }^{62}$ Dreher (1994).

${ }^{63}$ Jaworski (1993).

${ }^{64}$ Jaworski (1993) .

${ }^{65}$ Sjá nánar á www.kluweronline.com/issn/1382-3019/current (Journal of Market-Focused Management).

${ }^{66}$ Framkvæmd haustið 2000.

${ }^{67}$ Framkvæmd haustið 1999.
} 
sem á einhvern hátt höfðu orð á sér fyrir að veita góða pjónustu. Viðmælendur voru valdir í samráði við stjórnendur. Gagnaöflun stóð yfir í tvo mánuði og voru tekin fjögur 1-1,5 klst. löng viðtöl og prjár pátttökuathuganir. Pátttökuathuganirnar fólust annars vegar í pví að dvelja með tveimur viðmælenda hluta úr degi við störf peirra og hins vegar í að dvelja í pjónustukerfi Fyrirtækisins í einn dag.

Rannsóknarspurningarnar voru prjár:

1. Hvað prýðir góðan starfsmann Fyrirtækisins?

2. Нvaða umhverfislegu pættir virka hvetjandi til að veita góða pjónustu?

3. Hvaða hindranir standa í vegi fyrir pví að hægt sé að veita góða pjónustu?

Í viðtölunum var ekki fylgt ákveðnum spurningalista en lögð á pað áhersla að fjalla um ákveðin atriði eins og starfsferil, samskipti, skipulag og pjónustu. Framkvæmd viðtala sem pessara fara að nokkru leyti eftir reynslu pess sem peim stýrir en höfundur hefur gert á bilinu 600-700 greinandi viðtöl á undanförnum árum. Öll viðtöl voru tekin upp á segulband, pau skráð niður og unnið úr peim með hefðbundnum aðferðum. Margt af pví sem kemur fram í viðtölunum tengist forsendum markaðshneigðar og byggir pví greining höfundar á pví hvort Fyrirtækið geti aukið markaðshneigð að nokkur leyti á peim.

Seinni rannsóknin var óformleg að pví leyti að viðtöl voru ekki tekin upp og skráð með peim hætti sem gert var í fyrri rannsókninni. Umræðuramminn var hins vegar mjög skýr en par var beinlínis gengið út frá greiningarlíkani ${ }^{68}$ sem kennt er við Kohli og Jaworski og lögð á pað áhersla að skoða pær forsendur sem purfa að vera fyrir hendi svo um árangursríka innleiðingu verði að ræða. Pessum forsendum er skipt upp í prjú svið, hlutverk stjórnenda, samspil deilda, og skipulag. Sjá má líkanið á mynd 7. Rætt var við alla stjórnendur Fyrirtækisins, nokkra starfsmenn en einnig prjá stjórnendur annarra opinberra fyrirtækja.

Prátt fyrir að ekki megi yfirfæra pá greiningu sem hér er fjallað um yfir á öll opinber eða hálfopinber fyrirtæki og stofnanir, er ljóst að skipulagsheildir sem pessar eiga margt sameiginlegt. Гаð á ekki síst við um menningu, ytri aðstæður, stjórnun, samskipti og skipulag. Tilgangur greiningarinnar er að kanna hvort opinbert fyrirtæki á pjónustusviði geti aukið hjá sér markaðshneigð og hvað standi helst í vegi fyrir pví. аð eru einkum pessi atriði sem höfundur telur að megi yfirfæra að nokkru leyti á opinberan rekstur almennt.

${ }^{68}$ Sjá Kohli (1990), Jaworski (1993) og Dreher (1994). 


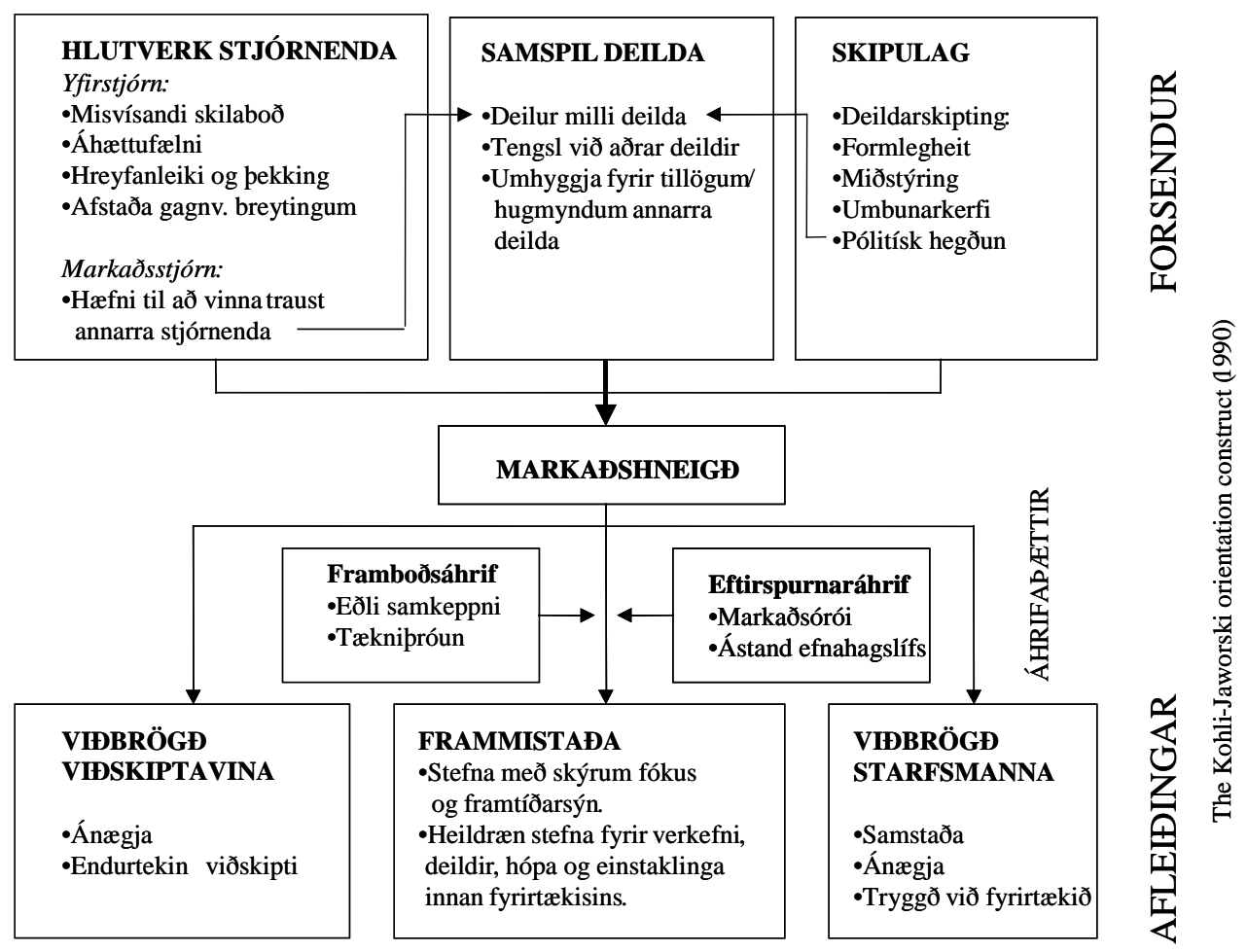

Mynd 7. Líkan Kohli og Jaworski um uppbyggingu markaðshneigðar.

Líkaninu, sem stuðst er við í umræðunni og sjá má á mynd 7, er skipt í prjá hluta sem eru forsendur, áhrifapættir og afleiðingar eða áhrif. Í framhaldinu verður gerð grein fyrir hverjum og einum hluta, með sérstaka áherslu á forsendur, og sú fræðilega umfjöllun tengd starfsumhverfi og starfsaðstæðum hins opinbera fyrirtækis.

\subsection{Forsendur markaðshneigðar}

Skilgreindir eru prír pættir sem forsendur fyrir pví að hægt sé að innleiða markaðshneigð. Pessir pættir eru hlutverk yfirstjórnenda, samspil deilda og skipulag. Með forsendum er átt við að innan hverrar skipulagsheildar séu ákveðnar aðstæður og fyrirkomulag, sem hefur áhrif á hversu auðvelt eða erfitt sé að auka markaðshneigð innan viðkomandi einingar.

\subsubsection{Páttur yfirstjórnenda}

Páttur yfirstjórnenda skiptir miklu máli ef takast á að innleiða markaðshneigð. Pannig er nauðsynlegt að yfirstjórnendur tileinki sér pá hugsun sem að baki markaðshneigðar býr og rugli henni ekki saman við sölu- eða auglýsingamennsku. Nauðsynlegt er að allir yfirstjórnendur tileinki sér pennan hugsunarhátt og láti hann koma fram í samskiptum sínum við aðra starfsmenn. ${ }^{69}$ Рað er pví líklegt að illa gangi аð innleiða markaðshneigð еða markaðsleg vinnubrögð, ef yfirstjórnendur tengja pann málaflokk aðeins við auglýsingar, aðrar kynningar eða sölustarf.•аð er dæmi um misvísandi skilaboð pegar yfirstjórnandi segist vilja vera markaðssinnaður en lætur ekki fylgja með nauðsynlegt fjármagn, mannafla og skipulag til að sinna peim verkefnum sem pví tengjast.

${ }^{69}$ Best (1997) sjá einnig Locander (2002). 
Segja má að Fyrirtækið hafi haft kjöraðstæður til að tileinka sér og innleiða ný vinnubrögð en við skipulagsbreytingar 1995 voru prír af fjórum yfirstjórnendum nýir og komu pví að fyrirtækinu án pess að vera bundnir af fortíðinni. ${ }^{70}$ Sex árum síðar sköpuðust aftur hliðstæðar aðstæður en pá voru gerðar skipulagsbreytingar og nýr forstjóri ráðinn.

Annar mikilvægur páttur sem snýr að yfirstjórnendum er viljinn til að taka áhættu en ef marka má rannsókn Jaworski (1993) og Kohli gerir innleiðing markaðshneigðar nánast kröfu um að ákveðin áhætta sé tekin svo hægt sé kynna nýjungar í vörupróun og nýsköpun, sem er nauðsynlegt til að mæta breytilegum pörfum á markaðinum. ${ }^{71}$ Hér er ekki átt við að stjórnendur eigi endilega að vera áhættusæknir. Reynslan sýnir að pað ganga ekki allar nýjar hugmyndir upp og pá parf viðhorfið að vera að læra eigi af mistökunum og að menn séu áfram hvattir til dáða.

Ætla má að á tímabilinu 1996-1999 hafi vilji og por yfirstjórnenda Fyrirtækisins til að taka áhættu aldrei verið meiri enda hafði pað gengið í gegnum meiri breytingar á pessum tíma en nokkru sinni áður. Sem dæmi um petta voru gerðar breytingar á grunnpjónustu fyrirtækisins og gengu pær í gildi árið 1996 eftir langan undirbúning. Par á undan hafði slík breyting ekki verið gerð síðan 1970, p.e. pjónustan hafði að grunni til verið óbreytt í aldarfjórðung. Í viðtölum við stjórnendur Fyrirtækisins kom fram að áhættufælni hefur ráðið mestu um að ekki var ráðist í svo viðamiklar breytingar fyrr. Vitað var að hluti breytinganna, sem tóku gildi 1996, myndi vekja hörð viðbrögð, bæði meðal peirra sem stóðu fyrir utan fyrirtækið, p.e. viðskiptavina og hagsmunaaðila, en ekki síður hjá starfsmönnum pess. Hluti breytinganna gekk út á að endurskoða með hvaða hætti pjónustan var framkvæmd og kom pví, í mörgum tilvikum, meira við starfsmenn en viðskiptavini.

Einnig voru innleiddar nýjar starfsaðferðir á pessum tíma, s.s. reglulegar mælingar og gæðaeftirlit, pjónustumat meðal viðskiptavina, markaðsrannsóknir og opnað var fyrir pjónustusíma par sem viðskiptavinir voru beinlínis hvattir til að kvarta og/eða koma með ábendingar um pað sem betur mætti fara í pjónustunni.

Á hinn bóginn verður að benda á pá staðreynd að fyrirtækið hafði yfir sér pólitíska stjórn. Раð gerði pað að verkum að áhættufælni yfirstjórnenda var til staðar og virtist fara vaxandi eftir pví sem peir voru búnir að vera lengur í starfi. Í viðtölunum, bæði peim formlegu og óformlegu, voru nefnd dæmi um að stjórnendur fyrirtækja leggja ekki út í vissar ákvarðanatökur, af ótta við viðbrögð úr hinu pólitíska umhverfi. Viðbrögðin, sem óttast er, geta verið margvísleg, s.s. refsing, illt umtal, einelti og aðrar ofsóknir sem yfirstjórnendur verða að sætta sig við, ýmist beint frá stjórnmálamönnum eða eftir öðrum leiðum, s.s. í gegnum hagsmunasamtök starfsmanna og/eða ýmis hagsmunasamtök íbúa.

Ekki er víst að óttinn eigi í öllum tilvikum við rök að styðjast en ef marka má pær upplýsingar sem komu fram í viðtölunum má ætla að hann sé fyrir hendi og endurspeglist í störfum yfirstjórnenda. Petta pyrfti hins vegar að kanna mun betur og gæti pað verið gert með viðtalarannsókn eða megindlegri rannsókn. Á pað skal pó bent að í viðtölum myndast, ef vel eru framkvæmd, trúnaður sem ekki fæst með

\footnotetext{
${ }^{70}$ Morgan (1997).

${ }^{71}$ Sjá einnig Morgan (1997).
} 
pví að leggja fyrir spurningalista. Раð kann pví að vera vissum takmörkunum háð að fá fram viðkvæmar trúnaðarupplýsingar með öðrum hætti en í viðtölum.

Hvað varðar stjórnun markaðsmála er mikilvægt að hafa í huga hvernig markaðsmál eru skilgreind. Mikilvægt er að markaðsmál séu ekki skilgreind pröngt, t.d. aðeins sem kynningarmál eða sölumál, heldur sem starfsemi sem allar deildir purfa að sinna með einum eða öðrum hætti. Pannig er mikilvægt að markaðsstjórinn efli tengsl sín við aðrar deildir, t.d. með pátttöku í verkefnum og próunarstarfi og leggi pannig sitt af mörkum til að koma í veg fyrir hugsanlegar deilur eða ágreining milli deilda.

\subsubsection{Samspil deilda}

Í rannsóknum Kohli (1990) og Jaworski (1993) er sérstaklega fjallað um samspil deilda. Tvær tilgátur eru nefndar par sem önnur segir að eftir pví sem ágreiningur er meiri á milli deilda, peim mun erfiðara er að auka markaðshneigð, en hin segir að eftir pví sem samspil og samvinna deilda er meiri peim mun auðveldara er að auka markaðshneigð. Í niðurstöðum rannsóknarinnar kemur fram að sterk tengsl eru parna á milli eins og tilgáturnar gengu út frá. ${ }^{72}$

Mikilvægt er að viðhafa starfsemi sem kemur í veg fyrir ágreining milli deilda og stuðlar að aukinni samvinnu peirra. Í kjölfar skipulagsbreytinga hjá Fyrirtækinu árið 1995 var tekið upp ákveðið fundakerfi. Pannig voru vikulega samráðsfundir forstöðumanna með forstjóra og reglulega samráðsfundir forstöðumanna og deildarstjóra. Einnig voru tekin upp ný vinnubrögð hvað varðar hópvinnu og aðkomu starfsmanna að verkefnum og var pað regla аð mynda pverfaglega vinnuhópa um öll stærri verkefni.

Prátt fyrir petta var nokkur brestur á fyrirkomulaginu. Sem dæmi voru afar sjaldan haldnir samráðsfundir milli deilda sem ekki heyrðu undir sama svið. Nokkuð bar á togstreitu á milli deilda, jafnvel peirra sem tilheyrðu sama sviði. Hér er komið að einu af grundvallaratriðum í markaðsfræðinni sem er að átta sig á pví hvert sé hlutverk tiltekinnar starfsemi innan fyrirtækisins. ${ }^{73}$ Starfsmenn í deild A áttu t.d. erfitt með að gera sér grein fyrir pjónustuhlutverki sínu gagnvart viðskiptavinum fyrirtækisins og starfsmenn í deild B áttu erfitt með að gera sér grein fyrir pjónustuhlutverki við deild A.

\subsubsection{Skipulag}

Ein af premur grundvallarforsendum fyrir innleiðingu markaðshneigðar, er skipulag. Par er fyrst og fremst horft til fimm pátta, deildarskipulags, formlegheita, miðstýringar, umbunarkerfis og pólitískrar hegðunar.

Starfsemi Fyrirtækisins var skipt í prjú svið, sem í sameiningu áttu að vinna að pví að fyrirtækið framfylgdi hlutverki sínu og næði markmiðum. Petta stjórnskipulag tók gildi 1995 og var ætlað að auka pjónustuhæfni og markaðsleg vinnubrögð.

\footnotetext{
72 Jaworski (1993).

${ }^{73}$ Kotler (1994) og Ryan (1996).
} 
Í tilgátum Kohli (1990) og Jaworski (1993) er gengið út frá pví að eftir pví sem formlegheit (e. formalization), miðstýring (e. centralization) og deildarhyggja (e. departmentalization) eru meira áberandi, peim mun erfiðara er að innleiða markaðshneigð. Ennfremur er sett fram tilgáta pess efnis að eftir pví sem umbunarkerfi/bónuskerfi tekur meira mið af markaðslegum gildum (e. market-based reward system), peim mun auðveldara er að innleiða markaðshneigð. Niðurstöður rannsóknarinnar benda til pess að sterk, jákvæð tengsl, séu milli umbunarkerfis og innleiðingar markaðshneigðar en að sama skapi séu sterk, neikvæð tengsl, milli miðstýringar og innleiðingar markaðshneigðar. ${ }^{74}$

Eðlilegt er pví að skoða sérstaklega pessa tvo pætti hjá Fyrirtækinu. Pó svo að nokkuð hafi dregið úr miðstýringu pá var hún enn til staðar og átti pað sérstaklega við gagnvart framlínufólki, prátt fyrir mikilvægi valddreifingar í pjónustufyrirtækjum. ${ }^{75}$ Ástæður fyrir pessu geta verið margar og má m.a. rekja til starfsumhverfis og menningar fyrirtækisins. Nokkurs konar hefð er fyrir miðstýringu í opinbera kerfinu og prátt fyrir að markmið gangi út á aukna valddreifingu pá er eins og illa gangi að koma henni á pegar til á að taka.

Vert er að leiða hugann að tveimur páttum sem skýringu á pessu. Í fyrsta lagi virðist ákveðið vantraust vera til staðar og í öðru lagi ber nokkuð á svokölluðum "smákóngahætti", en báðir pessir pættir eiga stóran pátt í pví hve illa gengur að dreifa valdi. ${ }^{76}$

Ekki var til staðar formlegt umbunarkerfi ${ }^{77}$ hjá Fyrirtækinu. Ef marka má niðurstöður Jaworski (1993) og Kohli er slíkt nauðsynlegt ef takast á að auka markaðshneigð. Ekki er sama hvernig umbunarkerfið er, pannig væri t.d. umbunarkerfi sem byggir á mætingum til vinnu ekki pað sem pyrfti til að auka markaðshneigð, heldur parf slíkt kerfi að taka mið af markaðslegum gildum og pá hve vel peim, sem eiga að fá umbun, tekst að uppfylla parfir og langanir viðskiptavinarins. Ein af forsendum fyrir pví er meðal annars valddreifing.

Margt bendir pví til að ætli stjórnendur opinberra fyrirtækja að auka markaðshneigð, purfi peir að finna leið til að auka valddreifingu innan fyrirtækisins, forma umbunarkerfi sem tekur mið af pví að uppfylla parfir viðskiptavinarins og gera starfsmönnum grein fyrir hverjar pær parfir eru.

\footnotetext{
${ }^{74}$ Jaworski (1993).

${ }^{75}$ Zeithaml (1996).

${ }^{76}$ Sjá Morgan (1997).

${ }_{77}$ Svo kallað bónuskerfi var í deild B en pað tók fyrst og fremst mið af afköstum og viðveru frekar en t.d. pjónustuvilja eða ánægju með pjónustu.
} 


\section{2 Áhrifapættir markaðshneigðar}

Í rannsóknum sínum nefna Kohli (1990) og Jaworski (1993) að ákveðnir ytri pættir geti haft áhrif á hve mikið markaðshneigð fyrirtækja skili sér í árangri peirra. Prátt fyrir að niðurstaða peirra sé sú að markaðshneigð skili sér alltaf í betri frammistöðu skipulagsheilda, óháð pessum ytri páttum, pá skal fjallað um pá stuttlega hér.

\subsubsection{Breytingar á markaði, órói}

Sett er fram sú tilgáta að pví meiri órói sem er á markaði (e. market turbulence), peim mun sterkari séu tengsl markaðshneigðar og árangurs. Með óróa á markaði er átt við hve örar breytingar eru á samsetningu viðskiptavina og væntingum peirra. Niðurstöður rannsókna Jaworski (1993) bentu til pess að sterk tengsl væri milli árangurs og markaðshneigðar, óháð pessum áhrifapætti.

Petta styður pá afstöðu Fyrirtækisins að hafa markaðsleg gildi að leiðarljósi78 pó svo að lítil breyting sé á samsetningu viðskiptavina og væntingum peirra. Hafa ber pó í huga að frá 1970 hafa orðið miklar breytingar á viðskiptavinahópnum og mun meiri kröfur eru gerðar til pjónustunnar nú en pá.

\subsubsection{Samkeppni}

Í rannsóknum Kohli (1990) og Jaworski (1993) er sett fram sú tilgáta að eftir pví sem samkeppnin er meiri, pví sterkari tengsl séu milli markaðshneigðar og árangurs. Niðurstaðan benti hins vegar til pess að prátt fyrir litla samkeppni mátti sjá jákvæð tengsl milli markaðshneigðar og árangurs skipulagsheildarinnar.

Раð skiptir að sjálfsögðu máli hvernig samkeppni og árangur er skilgreindur. Pannig má skilgreina samkeppni út frá tveimur sjónarhornum, annars vegar út frá atvinnugreininni og hins vegar út frá markaðinum eða pörfinni. ${ }^{79}$ Pegar samkeppni er skilgreind út frá atvinnugreininni er horft til fyrirtækja sem starfa í sömu grein, t.d. bílaframleiðendur, bílasalar, blómasalar, skólar o.s.frv. Pegar samkeppni er skilgreind út frá markaði er horft til parfa og markhópa og litið svo á að peir sem uppfylli sömu parfir eða pjóni sömu hópum, eigi í innbyrðis samkeppni, prátt fyrir að starfa í ólíkum greinum. Pannig gæti kvöldskóli átt í samkeppni við kvikmyndahús, par sem keppt er um sama tíma, og gólfefnasali gæti átt í samkeppni við ferðaskrifstofu, par sem keppt er um sömu peningana.

Fyrirtækið sem hér um ræðir hafði einkaleyfi til að veita pjónustu sína á markaðinum. Undir slíkum kringumstæðum er hætt við að litið sé pannig á að ekki sé um neina samkeppni að ræða. Á hinn bóginn eru til aðrar ólíkar leiðir til að fullnægja pörfunum sem fyrirtækið sinnir pannig að frá sjónarhóli parfanna eða markaðarins er samkeppni fyrir hendi. Pess vegna er mikilvægt að taka mið af samkeppninni í hinum víðara skilningi pegar hugleitt er hvort eigi að auka markaðshneigð.

\footnotetext{
${ }^{78}$ Kemur fram í stefnu Fyrirtækisins.

${ }^{79}$ Kotler (2001).
} 


\subsubsection{Tæknipróun}

Priðji pátturinn varðar tækniumhverfið og próun pess. Sett er fram tilgáta pess efnis að eftir pví sem tæknipróun sé örari á markaði, peim mun veikara samband sé milli markaðshneigðar og árangurs. Ef marka má niðurstöður Jaworski (1993) og Kohli pá er pessi tilgáta hrakin. Prátt fyrir öra tæknipróun virðast sterk tengsl milli markaðshneigðar og árangurs skipulagsheildar. Fyrirtæki sem starfar í umhverfi par sem tæknipróun er hröð, geti pví náð enn betri árangri með pví að auka markaðshneigð en að gera pað ekki.

\subsubsection{Efnahagsumhverfið}

Fjórða atriðið, sem Kohli (1990) og Jaworski (1993) setja fram sem tilgátu, snýr að almennu efnahagsástandi. Áhugavert er að skoða tilgátuna og bera hana saman við рað umhverfi sem Fyrirtækið starfar í. Tilgátan segir að eftir pví sem efnahagsástand er verra, peim mun sterkari tengsl séu milli markaðshneigðar og árangurs skipulagsheildarinnar.

Ef umhverfi Fyrirtækisins er skoðað má halda pví fram að pessu sé öfugt farið, p.e. eftir pví sem almennt efnahagsástand er betra, peim mun mikilvægari er markaðshneigð fyrir árangur pess og er pá átt við alla pætti tengda afleiðingunum, p.e. peim sem snúa að ánægju viðskiptavina, beinum rekstrarárangri og svo áhrif á starfsmannamál. Pegar efnahagsástand er gott pá gera viðskiptavinir Fyrirtækisins meiri kröfur vegna aukins kaupmáttar og kaup á staðgönguvöru verður einfaldlega raunhæfari kostur fyrir fleiri en ella. •аð er pví mjög mikilvægt við aðstæður sem pessar að sinna pörfum og óskum viðskiptavinanna eins vel og hægt er og hafa markaðsleg gildi að leiðarljósi. Með pví móti má koma í veg fyrir að fleiri yfirgefi pjónustuna en peir sem bætast við. Í góðu efnahagsástandi skapast einnig órói í starfsmannahópnum par sem eftirspurn eftir vinnuafli eykst og pá bjóðast starfsmönnum tækifæri sem gefa meira í aðra hönd en Fyrirtækið hefur ráð á.

Раð er pví margt sem bendir til pess að pessi tilgáta eigi alls ekki við um starfsumhverfi Fyrirtækisins, heldur pvert á móti geri gott efnahagsástand enn frekari kröfu til pess að fyrirtækið auki markaðshneigð í starfsemi sinni.

\subsection{Afleiðingar eða áhrif markaðshneigðar}

Í rannsóknum Kohli (1990) og Jaworski (1993) eru settar fram tilgátur sem tengjast afleiðingum eða ávinningi pess að innleiða markaðshneigð í skipulagsheild. Skipta má pessum ávinningi í prjá hluta, p.e. viðbrögð viðskiptavina, beina frammistöðu skipulagsheildar og viðbrögð starfsmanna.

\subsubsection{Viðbrögð viðskiptavina}

Ekki eru settar fram neinar beinar tilgátur í rannsóknum Kohli (1990) og Jaworski (1993) varðandi pennan pátt. аð er hins vegar almennur skilningur peirra sem tileinkað hafa sér markaðslegan hugsunarhátt og markaðsleg gildi að slíkt skili sér í aukinni ánægju viðskiptavina og tryggð peirra. Nægir í pví sambandi að benda á 
kenningar sem hafa komið fram um tengslamarkaðsfærslu ${ }^{80}$ (e. relationship marketing) ásamt hugmyndum varðandi tengsl ánægju viðskiptavina við gæði, pjónustu og virði. ${ }^{81}$ Hér er pví litið á að ávinningur af ríkri markaðshneigð skili sér í aukinni ánægju viðskiptavina og par með tryggð peirra við vörur fyrirtækisins.

\subsubsection{Bein frammistaða fyrirtækisins}

Samkvæmt Kohli (1990) og Jaworski (1993) er líklegt að áhrif markaðshneigðar, fyrir utan раð að skila betri hagnaði ${ }^{22}$, skili sér í stefnu með skýra áherslu og framtíðarsýn ásamt heildrænni stefnu fyrir verkefni, deildir, hópa og einstaklinga innan fyrirtækisins.

Hvað Fyrirtækið varðar, pá hafði fyrirtækið skýra mynd af hlutverki sínu og framtíðarsýn. ${ }^{83}$ Nokkuð vantaði pó upp á að um heildræna stefnu fyrir öll verkefni, deildir, hópa og einstaklinga innan pess hafi verið að ræða. Í skilgreiningu á hlutverki fyrirtækisins er lögð áhersla á frumkvæði, markvissa boðmiðlun, gæði og aðlögunarhæfni að breytilegum pörfum markaðarins. Ennfremur er lögð áhersla á hagkvæmni í rekstri, að fyrirtækið nýti sér tækninýjungar sem styðja starfsemina á hverjum tíma og að gengið sé út frá rekstrarlegum forsendum við ákvarðanatöku. Framtíðarsýnin gerði ráð fyrir að ímynd Fyrirtækisins einkenndist af virðingu, pjónustulund og vingjarnlegu viðmóti. Að fyrirtækið væri opið fyrir nýjungum og fljótt að bregðast við breyttum aðstæðum á markaði. Framtíðarsýnin gerði ennfremur ráð fyrir að fyrirtækið yrði pekkt fyrir að hafa markaðsleg gildi að leiðarljósi, yrði öflugt pjónustufyrirtæki og pekkt fyrir ábyrga starfsemi gagnvart umhverfinu.

Í eyrum einhverra kann petta að hljóma sem hver annar fagurgali, sem á sér litla stoð í raunveruleikanum. Að hluta til kann pað að hafa verið rétt en pó hafði pessi yfirlýsta stefna nýst við að ná fram ýmsum markmiðum sem purfti að ná til að tryggja velferð starfseminnar. Pannig var stefnan notuð í viðtölum við starfsmenn, t.d. pegar einhver hafði kvartað eða viðkomandi ekki unnið starf sitt sem skyldi. Stefnan var einnig grunnur margra verkefna sem voru sett af stað vegna pess að stefnan sem slík gerði ráð fyrir pví. Pannig má nefna reglulegar mælingar, greiningar, gæðaeftirlit, samráðsfundi, starfsmannaviðtöl, frammistöðumat og ýmis önnur verkefni sem fyrst og fremst eru til komin eftir skipulagsbreytingarnar sem tóku gildi 1995.

\subsubsection{Viðbrögð starfsmanna}

Samkvæmt rannsóknum Kohli (1990) og Jaworski (1993) getur markaðshneigð leitt til jákvæðara viðhorfs starfsmanna sem skilar sér í aukinni samstöðu á meðal peirra, ánægju og tryggð við fyrirtækið.

Segja má að hér hafi Fyrirtækið verið komið einna styst í próun sinni til aukinnar markaðshneigðar. Margt kemur til, s.s. menning en ekki síst, ef marka má pað sem

\footnotetext{
${ }^{80}$ Sjá t.d. Zeithaml (1996), Hollensen (2003) og Zinkhan (2002).

${ }^{81}$ Kotler (1994).

${ }^{82}$ Sjá Narver (1990).

${ }^{83}$ Kemur fram í stefnu fyrirtækisins.
} 
fram kom í viðtölum, pólitísk afskipti undangengin ár. Nauðsynlegt er að efla starfsemi, sem hefur pað að markmiði að styrkja pá pætti sem að framan eru taldir. Mikill kostnaður, bæði beinn og óbeinn, verður til pegar óánægja er til staðar hjá starfsfólki, ekki síst pegar um pjónustufyrirtæki er að ræða ${ }^{84}$ og væri pví mikill ávinningur af aukinni markaðshneigð á starfsmannamál.

Af umfjölluninni hér að framan má ráða að Fyrirtækið hafi að einhverju leyti tileinkað sér markaðshneigð og markaðsleg vinnubrögð. Ýmsir annmarkar koma pó í ljós við greiningu á stöðu fyrirtækisins, sem rekja má fyrst og fremst til menningar, sögu og skipulags pess. Pannig hafi miðstýring verið áberandi og nokkuð borið á togstreitu milli deilda en bæði pessi atriði eru talin standa í vegi fyrir pví að fyrirtæki geti aukið markaðshneigð sína. Ennfremur séu pólitísk áhrif ekki langt undan pegar um opinbera starfsemi er að ræða en pau geta tafið fyrir peirri vinnu sem stuðla að aukinni markaðshneigð.

\section{Lokaorð}

Markaðshneigð má lýsa sem fyrirtækjamenningu sem gerir ráð fyrir að allir starfsmenn einbeita sér að pví að veita viðskiptavininum sem mestan ávinning af viðskiptum/samskiptum sínum við skipulagsheildina. ${ }^{85}$ Til að petta sé gerlegt parf að greina aðstæður í markaðsumhverfinu, miðla peim upplýsingum innan skipulagsheildarinnar og tryggja að hegðun hennar taki mið af nýfenginni pekkingu. ${ }^{86}$ Leiðirnar sem skipulagsheildirnar hafa til að ná pessu fram eru öflugar markaðsrannsóknir, öflugt innra markaðsstarf og vel skilgreindir mælikvarðar á árangur. ${ }^{87}$

Í nútíma markaðsstarfi er lögð áhersla á prjú meginverkefni; greiningu, mótun stefnu og útfærslu markaðsáætlunar. Prátt fyrir að auglýsingar gegni ákveðnu hlutverki í markaðsáætlanagerð, hefur dregið úr pví mikilvægi. Auglýsingar eru liður í útfærsluhluta markaðsáætlanagerðarinnar, og pað sem meira er, aðeins eitt af ótal verkefnum par. ${ }^{88}$

Í pessari grein hefur verið lögð áhersla á að kynna markaðsáherslur og markaðshneigð. Fjallað hefur verið um upphaf og próun markaðsfræðinnar og gerð grein fyrir mismunandi áherslum sem fyrirtæki og stofnanir geta viðhaft í starfsemi sinni.

Pá fjallar höfundur um pað sjónarmið hvort opinber og hálfopinber fyrirtæki eða stofnanir geti eða ættu að tileinka sér markaðshneigð. Í pví sambandi er starfsumhverfi eins opinbers fyrirtækis skoðað í ljósi rannsókna Kohli (1990) og Jaworski (1993). Par er fjallað um forsendur, áhrifapætti og afleiðingar markaðshneigðar. Af umfjölluninni má ráða að Fyrirtækið hafi að einhverju leyti tileinkað sér markaðshneigð og markaðsleg vinnubrögð. Ýmsir annmarkar koma pó í ljós við greiningu á stöðu fyrirtækisins, sem rekja má fyrst og fremst til menningar,

\footnotetext{
${ }^{84}$ Zeithaml (2003), sjá einnig Leland (1995), Lovelock (2002) og Haksever (2000).

${ }^{85}$ Narver (1998).

${ }^{86}$ Kohli (1990).

${ }^{87}$ Kotler (2001).

88 Kotler (2001).
} 
sögu og skipulags pess. Pannig hafi miðstýring verið áberandi og nokkuð borið á togstreitu milli deilda, en bæði pessi atriði eru talin standa í vegi fyrir pví að fyrirtæki geti aukið markaðshneigð. Ennfremur séu pólitísk áhrif ekki langt undan pegar um opinbera starfsemi er að ræða en pau geta tafið fyrir peirri vinnu sem stuðla að aukinni markaðshneigð.

Nauðsynlegt er að gera magnbundna rannsókn til að kanna hvernig staða markaðshneigðar er hjá opinberum fyrirtækjum. Til eru nokkrir staðlaðir spurningalistar, s.s. MARKOR ${ }^{89}$ og $\mathrm{MKTOR}^{90}$. Pessi mælitæki hafa pó verið gagnrýnd og m.a. bent á að mæliaðferðin og úrtakið sé í eðli sínu framleiðslumiðað í stað pess að vera markaðsmiðað. ${ }^{11}$ Einnig hefur MARKOR mælikvarðinn tekið nokkrum endurbótum frá sinni upphaflegu mynd. ${ }^{92}$ Pað er pví ljóst að töluverða vinnu pyrfti til að hanna mælitæki sem legði mat á markaðshneigð hjá opinberum fyrirtækjum eða stofnunum.

\section{Heimildir}

Adcock, D., Bradfield, R., Halborg, A., \& Ross, C. (1998). Marketing, Principles and Practice. London: Financial Times Management.

Anreasen, A. R., \& Kotler, P. (2003). Strategic Marketing for NonProfit Organization. New Jersey: Prentice Hall.

Bagozzi, R. P., Rosa, J. A., Celly, K. S., \& Coronel, F. (1998). Marketing Management. New Jersey: Prentice Hall.

Baker, M. (2003). The Marketing Book. Oxford: Butterworth-Heinemann.

Baker, W. E., \& Sinkula, J. M. (1999). Learning Orientation, Market Orientation, and Innovation: Integrating and Extending Models of Organizational Performance. Journal of Market Focused Management, 4, 295-308.

Baker, W. E., \& Sinkula, J. M. (2002). Market orinetation, Learning Orientation and Product Innovation: Delving into the Organization's Black Box. Journal of Market Focused Management, 5, 5-23.

Belch, G. E., \& Belch, M. A. (2001). Advertising and Promotion, An Integrated Marketing Communications Perspective. New York: Irwin/McGraw-Hill.

Best, R. J. (1997). Market-Based Management, Strategies for Growing Customer Value and Profitability. New Jersey: Prentice Hall.

Bisp, S. (1999). Barriers to Increased Market-Oriented Activity: What the Literature Suggests. Journal of Market Focused Management, 4, 77-92.

Converse, P. D. (1951). Development of Marketing Theory: Fifty Years of Progress. Changing Perspectives in Marketing, 1-31

\footnotetext{
89 Jaworski (1993).

${ }^{90}$ Narver (1990).

${ }^{91}$ Farrell (2002).

92 Matsuno (2000).
} 
Day, G. S., \& Wensley, R. (1983). Marketing Theory with a Strategic Orientation. Journal of Marketing, 47, 79-89.

Day, G. S. (1999). Misconceptions about Market Orientation. Journal of Market Focused Management, 4, 5-16.

Dreher, A. (1994). Marketing Orientation: How to Grasp the Phenomenon. Perspectives on Marketing Management, 4.

Farrel, M. (2002). A Critique of the Development of Alternative Measures of Market Orientation. Marketing Bulletin, 13.

Farrell, M. A., \& Oczkowski, E. (2002). Are Market Orientation and Learning Orientation Necessary for Superior Organizational Performance? Journal of Market Focused Management, 5, 197-217.

Hagstofa Íslands (1999). Fjölmiðlun og menning. Reykjavík: Hagstofa Íslands.

Haksever, C., Render, B., Russel, R. S., \& Murdick, R. G. (2000). Service Management and Operarions. New Jersey: Prentice Hall.

Hammel, G., \& Prahalad, C.K. (1996). Competing for the Future. Harvard Business School Press.

Hill, E., \& O'Sullivan (1996). Marketing. London: Addison Wesley Longman Ltd.

Hollensen, S. (2001). Global Marketing, A market-responsive approach. Essex: Pearson Education Ltd.

Hollensen, S. (2003). Marketing Management, A Relationship Approach. Essex: Pearson Education Ltd.

Hunt, S. D. (1976). The Nature and Scope of Marketing. Journal of Marketing, 40, 17-26.

IM Gallup (1999). Viðhorfskannanir fyrir SVR. Reykjavík: IM Gallup.

Jaworski, B. J., \& Kohli, A. K. (1993). Market Orientation: Antecedents and Consequences. Journal of Marketing, 57, 53-70.

Kohli, A. K., \& Jaworski, B. J. (1990). Market Orientation: The Construct, Research Propositions, and Managerial Implications. Journal of Marketing, 54, 1-18.

Kotler, P. (1986). Megamarketing. Harvard Business Review. Mars-April.

Kotler, P. (1994). Marketing Management, Analysis, Planning, Implementation and Control. New Jersey: Prentice Hall.

Kotler, P. (2002). Marketing Management. New Jersey: Pearson Education.

Kotler, P. (2003). Marketing Insights From AtoZ. New Jersy: John Wiley \& Sons.

Kotler, P., Armstrong, G., Saunders, J., \& Wong, V. (2001). Principles of Marketing. Essex: Pearson Education Limited.

Levitt, T. (1960). Marketing Myopia. Harvard Business Review.

Locander, W. B., Hamilton, F., Ladik, D., \& Stuart, J. (2002). Developing a Leadership-Rich Culture: The Missing Link to Creating a Market-Focused Organization. Journal of Market Focused Management, 5, 149-163. 
Lovellock, C., \& Wright, L. (2002). Services Marketing and Management. New Jersey: Prentice Hall.

Morgan, G. (1997). Images of Organization. London: SAGE Publications.

Matsuno, K., Mentzer J. T., \& Rentz, J. O. (2000). A Refinement and Validation of the MARKOR Scale. Journal of the Academy of Marketing Science, 28.

Narver, J. C., Slater, S. F., \& Tietje, B. (1998). Creating a Market Orientation. Journal of Market Focused Management, 2, 241-255.

Narver, J. C., \& Slater, S. F. (1990). The Effect of a Market Orientation on Business Profitability. Journal of Marketing, October.

Peter, J. P., \& Donnelly, J. H. (2001). Marketing Management, Knowledge and Skills. Singapore: McGraw-Hill Higher Education.

Probst, G., \& Buchel, B. (1997). Organizational Learning, The Competitive Advantage of the Future. Essex: Prentice Hall Europe.

Ries, A., \& Ries, L. (2002). The Fall of Advertising and the Rise of PR. Harper Collins Publishers Inc.

Ryan, C. (1996). The Master Marketer. London: Kogan Page Ltd.

Webster, F. E. (1992). The Changing Role of Marketing in the Corporation. Journal of Marketing, 56, 1-17.

Winer, R. S. (2000). Marketing Management. New Jersey: Prentice-Hall.

Zeithaml, V. A., \& Bitner, M. J. (1996). Services Marketing. New York: McGraw-Hill Higher Educaton.

Zeithaml, V. A., \& Bitner, M. J. (2003). Services Marketing, Integrating Customer Focus Across the Firm. New York: McGraw-Hill Higher Educaton.

Zinkhan, G. M. (2001). Relationship Marketing: Theory and Implementation. Journal of Marketing, 5, 83-89.

Pórhallur Örn Guðlaugsson (2001). Er pjónustuvilji allt sem parf? Reykjavík: Höfundur.

Pórhallur Örn Guðlaugsson (2003). Mat á staðfærslu við mótun markaðsstefnu. Í Ingjaldur Hannibalsson (Ritstj.) Rannsóknir í félagsvísindum IV (bls. 425-434).

Reykjavík: Háskólaútgáfan. 
